\title{
The biogeochemistry of mercury at the sediment water interface in the Thau lagoon. 1. Partition and speciation
}

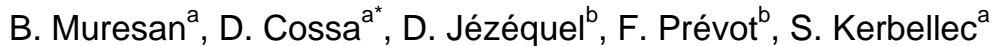

\author{
${ }^{a}$ Institut français de recherche pour l'exploitation durable de la mer (IFREMER), BP 21105, F.44311 \\ Nantes Cedex 03, France \\ ${ }^{\mathrm{b}}$ Laboratoire de Géochimie des Eaux (LGE), UMR CNRS 7047 - Université D. Diderot \& IPGP - Case \\ postale 7052, 4, Place Jussieu, F.75251 Paris Cedex 05, France
}

*: Corresponding author : Email address : dcossa@ifremer.fr

\begin{abstract}
Solid sediment, pore and epibenthic waters were collected from the Thau lagoon (France) in order to study the post depositional partition and mobility of mercury and monomethylmercury in an organic rich sediment. Total $\mathrm{Hg}(\mathrm{HgT})$ and monomethymercury $(\mathrm{MMHg})$ profiles were produced in both dissolved and solid phases. The distribution of $\mathrm{HgT}$ in the solid appeared to be related to the historical changes in the $\mathrm{Hg}$ inputs into the lagoon. $\mathrm{HgT}$ was in equilibrium between solid and solution in the sulfidic part of the cores, with a mean log $\mathrm{Kd}$ of $4.9 \pm 0.2$. The solid appeared to be a source of $\mathrm{HgT}$ for pore water in the upper oxic to suboxic parts of the cores. The MMHg represented a small fraction of HgT: $3-15 \%$ and $0.02-0.80 \%$ in the dissolved and in the solid phases respectively. Its distribution was characterized by a main peak in the superficial sediments, and another deeper in the core within the sulfide-accumulating zone. In addition, high dissolved $\mathrm{MMHg}$ concentrations and methylated percentage were found in the epibenthic water. Ascorbate $(\mathrm{pH} 8)$ dissolution of the sediments and analyses of the soluble fraction suggest that the amorphous oxyhydroxides played a major role in controlling total and methylmercury mobility throughout the sediment water interface. These features are discussed in term of sources, transfer and transformations. Diffusive fluxes of $\mathrm{HgT}$ and $\mathrm{MMHg}$ from sediment to the water column for the warm period were estimated to be $40 \pm 15$ and $4 \pm 2$ pmol $\mathrm{m}^{-2} \mathrm{~d}^{-1}$ respectively.
\end{abstract}

Keywords: Mercury; Methylmercury; Lagoon; Sediment; Partition; Fluxes 


\section{Introduction}

The toxicological concern regarding the bioaccumulation of mercury in aquatic food chains, mainly as monomethylmercury (MMHg), has given rise to extensive surveys of $\mathrm{Hg}$ concentrations and speciation in coastal environments, including water, sediments and biota (e.g., Bloom et al., 2004). There now exists a plethora evidence that near-shore sediments are repository sites for natural and anthropogenic Hg and are a significant source of MMHg for the marine food web (e.g., Bloom et al., 1999; Cossa and Gobeil, 2000). As a matter of fact, sediments have long been recognized as the main location for microbial Hg methylation especially within the redox transition zone containing sulfate-reducing bacteria (SRB) [e.g., Jensen and Jernelov, 1969; Gilmour et al., 1992; King et al., 1999; Mason et al., 1999; Benoit et al., 2003]. Several studies have recently prompted significant progress in the understanding of the methylating potential of sedimentary environments. Firstly, total mercury in the solid $\left(\operatorname{HgT}_{\mathrm{P}}\right)$ can be considered as a proxy for the substratum for Hg methylation, given that it is positively correlated with MMHg in surface sediments (Benoit et al., 2003). Secondly, the $\mathrm{MMHg}$ concentration in the solid (MMHg$)$ is an indication of the relative methylation rate (Bloom et al., 1999; Gilmour et al., 1998). Thirdly, the sulfide concentration, through the speciation and bioavailability of various Hg-S complexes, is thought to be a major factor controlling the bacterial methylation of inorganic mercury (Craig and Moreton, 1986; Benoit et al., 1999, 2001). In the fourth place, physical and/or biological turbations have been shown to alter the thickness of the suboxic layer and subsequently the amplitude of the methylation potential (Benoit et al., in press; Hammerschmidt and Fitzgerald, 2004; Sunderland et al., 2004). In short, the magnitude and the dynamics of the redox interface, and the processes that govern the availability of inorganic $\mathrm{Hg}$ for SRB in the suboxic zone are the key for understanding the methylation potential of a particular sedimentary environment. As a consequence, the bioavailability can be approached by speciation and partition measurements in a well-described redox system. In order to reach this goal, it is necessary to know the distribution of inorganic and methylated mercury species in the dissolved and the particulate phase of the sediment (Fe and Mn oxyhydroxides, Fe sulfides, particulate organic matter, etc.).

The Thau lagoon on the Mediterranean French coast is a pertinent environment for studying element exchanges at the sediment water interface (SWI). Firstly, the water column is shallow, providing a relatively high sediment area to water volume ratio. The lagoon also has a tendency to eutrophication leading to sulfidic sediments, especially in its shellfish- 
farming zone. With its permanent riverine, karstic and anthropic inputs, the Thau lagoon may therefore behave as a significant reactor for mercury methylation towards oxic-anoxic interfaces. This paper introduces and appraises the distribution of HgT and MMHg in the solid phase and pore water of sediment cores collected in the Thau lagoon, in order to study the post depositional partition and mobility of mercury. In order to ensure the most favorable conditions for biotic methylation, the pore water study was performed during the productive periods (spring and summer). Additionally, the likelihood for Fe and Mn oxyhydroxides sequestration of $\mathrm{HgT}$ and $\mathrm{MMHg}$ in the superficial sediment was examined through $\mathrm{pH} 8$ ascorbate extraction. Finally, the average molecular diffusion fluxes for total dissolved mercury $\left(\operatorname{HgT}_{\mathrm{D}}\right)$ and dissolved monomethylmercury $\left(\mathrm{MMHg}_{\mathrm{D}}\right)$ were calculated on the basis of the gradient at the SWI.

\section{Material and methods}

\subsection{Sample collection}

All the samples were collected within an area of $10 \mathrm{~m}$ x $10 \mathrm{~m}$ around Station C5 in the Thau lagoon (43²5'990N; 3³9’656E, Fig. 1). Water column and sediments were sampled during the different seasons from December 2001 to June 2004 (Table 1). Coring for pore water investigations were collected in May 2003 and in June 2004. The May 2003 sampling campaign (MB-5) was mainly devoted to mercury and methylmercury partitions in the sediment, with special attention being paid to spatial variability: 4 cores (noted \#1, \#2, \#3 and \#4) were taken at a $1 \mathrm{~m}$ distance from each other. The first one was close to the culture table on which the oysters are farmed, last was 4 m away. The June 2004 sampling campaign (MB6) focused on methylmercury affecting processes at the SWI and in the epibenthic waters.

The ultra clean sampling techniques and analytical methods applied for water analyses are those presented and discussed in detail by Bloom (1989) and Cossa et al. (2002 and 2003). In short, water column samples were collected by pneumatic pumping (an all Teflon double bellow ASTI pump) using acid-cleaned Teflon coated tubing. Samples were stored in acidclean Teflon (PFA) bottles. Sediments were collected by divers using Teflon or Plexiglas corers. Sectioning was performed in a glove box under nitrogen when pore waters had to be extracted; otherwise it was performed in air. The sulfide-accumulating zone (SAZ) was identified with sulfide sensitive sellotape, through the formation of a surface darkening Ti-S complex (Jézéquel et al., this issue). Interstitial waters were extracted immediately after 
sampling by centrifugation (4000 rpm, $20 \mathrm{~min}$ ) and subsequent filtration of the supernatant (Millipore $^{\circledR} 0.45 \mu \mathrm{m}$ hydrophilic Teflon LCR filters) in accordance with Gobeil and Cossa (1993). Samples of water overlying the sediments were kept by divers for further comparison with the pore water. All water samples were acidified with $1 \%(\mathrm{v} / \mathrm{v})$ Suprapur ${ }^{\circledR} \mathrm{HCl}$, double bagged and stored at $+4^{\circ} \mathrm{C}$ in dark conditions until analyses were performed.

In June 2004 (MB-6), poral and epibenthic waters were additionally collected through the use of dialysis devices also called classic peepers (Mason et al., 1998). Classic peepers are compartmented probes, which are implanted into the sediment by divers. Compartments (or cells) integrate dissolved species distribution over a $20 \mathrm{~mm}$ depth interval. Two porous membranes (Millipore ${ }^{\circledR} 0.2 \mu \mathrm{m}$ PVDF) ensure the bilateral diffusion and partition of dissolved species from poral and/or bulk water to the immediate Plexiglas cell (cell thickness: $1 \mathrm{~cm}$; sample volume: $10 \mathrm{~mL}$ ). Prior to in situ implantation, cells were filled with spring water with low HgT concentration ( $<1 \mathrm{pM}$, Cristalline ${ }^{\circledR}$ ), peepers were put into a water-filled plastic bag and dissolved oxygen was removed by bubbling for 12 hours with purified (iodided charcoal trap) nitrogen. The peeper was retrieved from the sediment after 8 days of equilibration. Peeper transportation and pore water sampling were performed under a nitrogen atmosphere. Peeper water was drawn in clean Teflon Oak-Ridge tubes and subsequently acidified with $200 \mu \mathrm{L} \mathrm{HCl}$ (Suprapur ${ }^{\circledR}$ ). Two sediment cores were collected within $50 \mathrm{~cm}$ distance on both sides of the peeper. These provided centimetric scale solid phase data on water content, porosity, loss on ignition (LOI), HgT, MMHg in Fe and Mn oxyhydroxides.

Pore and epibenthic waters were filtrated at $0.45 \mu \mathrm{m}$, while the peeper dialyses were performed through a $0.22 \mu \mathrm{m}$ membrane. Given that Hg species might be associated with particles sizing between 0.2 and $0.45 \mu \mathrm{m}$, a cross comparison was made of the results of the two different filtration techniques. The mean dissolved HgT concentrations in water collected near the sediment (5-10 $\mathrm{cm}$ above the SWI) were $15 \pm 4 \mathrm{pM}$ when using peepers and $12 \pm 3 \mathrm{pM}$ using a Teflon bottle handled by a diver. The former was filtered through $0.2 \mu \mathrm{m}$ and the latter through $0.45 \mu \mathrm{m}$ membrane. It appears that no significant difference exists whatever the cutting size chosen. Similar results were found in Lavaca Bay (Mason et al., 1998): filtering through a $0.1 \mu \mathrm{m}$ filter did not remove more $\mathrm{MMHg}$ or total $\mathrm{Hg}$ than filtration through a 0.45 $\mu \mathrm{m}$ filter.

\subsection{Sample analysis}

In the field measurements for $\mathrm{pH}$ (Unisense $\mathrm{pH}$ and reference electrode protected against sulfide contamination with a seawater junction and calibration was performed with 
NBS pH buffers) and total sulfides (colorimetric determination of $\mathrm{\Sigma H}_{2} \mathrm{~S}$ concentrations by the methylene blue method, Spectroquant ${ }^{\circledR} 14779$ Merck kit) were carried out from the classic peeper samples. Loss on ignition (LOI) was determined as a proxy for organic matter content by measuring the weight loss on lyophilized sediment after 24 hours at $450^{\circ} \mathrm{C}$. Porosity was derived from pore water and total sediment volumes and calculated in accordance with Boudreau (1996, see below). All mercury species in water samples were detected by cold vapor atomic fluorescence spectrometry (AFS). Dissolved $\mathrm{HgT}_{\mathrm{D}}$ was determined in compliance with Bloom and Fitzgerald (1988), by the formation of volatile elemental $\mathrm{Hg}$ (released by $\mathrm{SnCl}_{2}$ reduction, after 30 minutes of acidic $\mathrm{BrCl}$ oxidation, and its preconcentration on a gold column). Dissolved "reactive mercury" ( $\left.\mathrm{HgR}_{\mathrm{D}}\right)$, an easily reducible fraction, was obtained within 4 hours of sampling by direct reduction with $\mathrm{SnCl}_{2}$. An automatic atomic absorption spectrometer (AAS: AMA-254 ${ }^{\circledR}$, Altec Ltd.) was used for $\operatorname{HgT}_{\mathrm{P}}$ determinations in the solid phase of the sediments. This technique consists of a calcination of the freeze-dried samples under an oxygen gas stream in order to produce elemental mercury vapor and its subsequent amalgamation on a gold trap; mercury vapor then being measured by AAS (Cossa et al., 2002). The detection limits, defined as 3.3 times the standard deviation of the blanks, were $0.1 \mathrm{pM}$ and $0.035 \mathrm{nmol} \cdot \mathrm{g}^{-1}$ for the dissolved and particulate mercury analyses respectively. The corresponding reproducibilities (the coefficient of variation in percentage of five replicate samples) were lower than $10 \%$. The accuracy for HgT determinations in solids was regularly checked using the reference material (MESS-3) from the National Council of Canada as certified reference material (CRM). Monomethylmercury was determined using the method initially proposed by Bloom (1989) and modified by Liang and al. (1994). $\mathrm{MMHg}_{\mathrm{D}}$ in acidified water was extracted by $\mathrm{CH}_{2} \mathrm{Cl}_{2}$ and then transferred into $40 \mathrm{~mL}$ of Milli-Q water by evaporating the organic solvent. The aqueous solution was analyzed for $\mathrm{MMHg}$ by chromatography after ethylation and adsorption/desorption on a Tenax ${ }^{\circledR}$ column. For $\mathrm{MMHg}_{\mathrm{P}}$ a 3 hour acidic dissolution $\left(\mathrm{HNO}_{3}\right.$ $65 \%$ of approximately $200 \mathrm{mg}$ freeze-dried sediments took place before the procedure described previously. Detection limits were $0.05 \mathrm{pM}$ and $0.005 \mathrm{pmol} \cdot \mathrm{g}^{-1}$ for respectively a 20 $\mathrm{mL}$ water and $200 \mathrm{mg}$ solid sample. Precision was less than $10 \%$ for all analyses. Using the available reference material (IAEA-405), the accuracy of the method was estimated to be less than $5 \%$ with $91 \pm 8 \%$ recovery. This technique was adapted from Leermarkers et al. (2001) and the detailed procedure is given by Cossa et al. (2002 and 2003). 
The amorphous oxyhydroxides fraction of the sediment was extracted by partial dissolution using ascorbic acid/citric acid (1/2.5 w/w) at $\mathrm{pH} 8$, according to Kostka and Luther (1994). Iron and manganese present in the pore water $\left(\mathrm{Fe}_{\mathrm{D}}\right.$ and $\left.\mathrm{Mn}_{\mathrm{D}}\right)$ and in the oxyhydroxides $\left(\mathrm{Fe}_{\mathrm{Ox}}\right.$ and $\left.\mathrm{Mn}_{\mathrm{Ox}}\right)$ were measured by flame atomic absorption spectrometry (Varian, SpectrAA 600). Total $\left(\mathrm{HgT}_{\mathrm{Ox}}\right)$ and methylmercury (MMHgox $)$ in this fraction were also determined using the same methods as for $\operatorname{HgT}_{\mathrm{D}}$ and $\mathrm{MMHg}_{\mathrm{D}}$. All the analyses except $\mathrm{HgR}_{\mathrm{D}}$ determinations were performed within 2 months of sampling at the IFREMER laboratory of Nantes, France.

2.3 Modeling the diffusive fluxes

$\mathrm{MMHg}_{\mathrm{D}}$ and $\mathrm{HgT}_{\mathrm{D}}$ diffusive fluxes were estimated at the C5 benthic boundary layer (BBL) using Fick’s first law:

$$
\mathfrak{I}=-\left(\varphi \cdot D_{\mathrm{w}} / \theta^{2}\right) \cdot(\partial \mathrm{C} / \partial \mathrm{x})_{\mathrm{BBL}}
$$

Where $\mathfrak{I}$ is the flux of a solute with concentration $\mathrm{C}$ at the depth $\mathrm{x}, \varphi$ is sediment porosity, $\theta$ is tortuosity, and $\mathrm{D}_{\mathrm{w}}$ is the molecular diffusion coefficient of the solute in seawater. Measuring porosity the tortuosity was approached using Boudreau's formulation:

$$
\varphi=\frac{\text { pore water volume }}{\text { solid volume }+ \text { pore water volume }} \quad \theta^{2}=1-\ln \left(\varphi^{2}\right)
$$

The $\mathrm{D}_{\mathrm{w}}$ for $\mathrm{MMHg}_{\mathrm{D}}$ as $\mathrm{MMHgCl}$ and $\mathrm{HgT}_{\mathrm{D}}$ as $\mathrm{HgCl}_{4}{ }^{2-}$ were determined coupling the linear regressions of the infinite-dilution diffusion for cations and anions against temperature (Boudreau, 1996) with the infinite-dilution diffusion for ion pairs (Applin and Lasaga, 1984). The expression was calculated for temperature salinity and pressure from an empirical equation developed by Kukulka (1987). The adjustment for pore water viscosity of normal seawater was small at no more than $7 \%$ ( $\mathrm{Li}$ and Gregory, 1974). The respective approximations for $\mathrm{MMHg}_{\mathrm{D}}$ and $\mathrm{HgT}_{\mathrm{D}}$ at $\mathrm{T}=18^{\circ} \mathrm{C}, \mathrm{S}=35$ and $\mathrm{P}=2$ bar were $1.84 \cdot 10^{-5}$ and $8.65 \cdot 10^{-6} \mathrm{~cm}^{2} \cdot \mathrm{s}^{-1}$.

\section{The Thau lagoon: environmental settings}

The Thau lagoon is situated on the French Mediterranean coast and spans $70 \mathrm{~km}^{2}$ from $43^{\circ} 20^{\prime}$ to $43^{\circ} 28^{\prime}$ North and $3^{\circ} 31^{\prime} 50^{\prime \prime}$ to $3^{\circ} 42^{\prime} 30^{\prime \prime}$ East. With a mean depth of $5 \mathrm{~m}$ the residence times of water varies from 1 to 5 months (Péna and Picot, 1991). The Thau lagoon is divided into three sectors: one can find the "Crique de l'angle" to the northeast, the "Eaux 
blanches" lagoon to the southeast and the main sector called "Grand Etang”. The lagoon is connected to the Mediterranean Sea via 3 navigable channels. Mean salinity is about 35 but can vary with the season from 28 to 37 (Millet, 1989). The "La Vène" and "le Pallas" rivers are the principal freshwater inputs into the system. A karstic resurgence ("la Vise”) is also located in the "Crique de l'angle” area. Shellfish breeding and tourism make the Thau basin an important place for studying the mobility of mercury and methylation processes within a lagoon environment. The investigation site (C5), northeast of "Grand Etang”, is located inside the shellfish farming district (Fig. 1).

The Thau lagoon trace metals distributions in sediments can be divided into 3 distinct areas (Péna and Picot, 1991): (i) the west side with low contamination, low organic matter (OM) content and low fine particulate fraction $(<63 \mu \mathrm{m})$ levels, (ii) the central region (a sink for fine suspended particles) with moderate contamination levels, (iii) the north side with high trace metals concentrations, high organic carbon content and a high fine particulate fraction. Recent measurements have shown concentrations of organic carbon of up to $4.4 \%$ at Station C5 (Mesnage et al., this issue).

The C5 site (located in the northern area) underwent anthropogenic inputs of $\mathrm{Cu}, \mathrm{Cd}$ and TBT (RNO, 1998 and 1999). Sediment in C5 displayed a high proportion (> $90 \%$ ) of the fraction below $63 \mu \mathrm{m}$ over the fraction below $2 \mathrm{~mm}$. These were essentially composed of detritic quartz, aragonite, calcite and clays (Péna and Picot, 1991). LOI profiles were homogenous towards the surface (within the first $45 \mathrm{~mm}$ ) and decreased semi-exponentially with depth. Negative redox potentials (down to $-415 \mathrm{mV}$ ) coupled to high OM concentrations and summer hypoxic events accounted for a degraded ecosystem with a low diversity index (Calvario et al., 1989).

The water column was sampled in order to characterize the mercury speciation at a preliminary stage of the project. Figure 2 shows the vertical profiles obtained in a winter (MB-1, December 2001) and a summer cruise (MB-3, August 2002). During the winter cruise, the water column was stratified with a thermocline between 5 and $7 \mathrm{~m}$, whereas the water was more homogeneous during the summer cruise (MB-3) with a warmer layer between 1 and $3 \mathrm{~m}$. Mercury speciation measurements were performed on unfiltered water samples collected every meter down to $50 \mathrm{~cm}$ from the bottom (Fig. 2). Total mercury concentrations varied from 2.9 to $5.5 \mathrm{pM}$ in summer and 1.4 to $2.5 \mathrm{pM}$ during the winter cruise. The vertical distributions did not show any relationship with the stratification; in addition, it is more likely that the distributions were governed by the suspended matter distribution (Fig. 2). In fact, the 
dissolved fraction for HgT varied between 34 and $58 \%$, in the water column during the summer 2002 cruise, with the highest proportion in the first four meters. The proportion of reactive mercury (HgR/HgT), composed mostly of inorganic and labile organic mercury complexes, varied between 12 and $67 \%$, with the highest level found in surface water in winter. It is worthwhile noting the dissolved gaseous mercury (DGM, consisting mainly of $\mathrm{Hg}^{0}$ ) and $\mathrm{MMHg}$ vertical distributions. Concentrations were fairly homogeneous as far down as $6 \mathrm{~m}$, but there was a bulge in MMHg concentrations at 1 and $2 \mathrm{~m}$ with the peaks in HgT and HgR. More striking were the significant increases in concentrations approaching the bottom (Fig. 2). In short, the vertical structures of mercury species in the water column indicate that (i) a large proportion of mercury is associated with the particulate phase, especially during the productive period within the photic layer, and (ii) that the concentration increase in several species near the bottom reveals an effect of the benthic layer by particulate matter resuspension or/and by diffusive processes at the SWI. These preliminary results favor the choice of this particular environment (C5) for studying the mercury transformation and exchanges at the benthic layer.

\section{Results}

\subsection{Sediment characterization}

The mean sedimentation rate at Station C5 was $0.25 \mathrm{~cm} \mathrm{a}^{-1}$ according to Schmidt et al. (this issue). The sediment received strong but irregular particulate organic carbon fluxes (up to $4.4 \%$ according to Mesnage et al., this issue and LOI up to $20 \%$ in our own cores). All the diagenetic series took place within the upper centimeters of the sediment. Chemical gradients were very sharp, generating relatively significant fluxes. Oxygen penetration depth never exceeds $1.5 \mathrm{~mm}$ in winter and was less than $1 \mathrm{~mm}$ in May 2003 (Dedieu et al., this volume). In addition, this can be virtually zero during a "malaigue" crisis (the total anoxia of the water column). The reduction in $\mathrm{Fe}$ and $\mathrm{Mn}$ oxides took place just below this thin oxic layer (Metzger et al., this issue). Dissolved iron layers were thin enough to be less than $5 \mathrm{~mm}$ during the sampling periods (May 2003, MB-5), June 2004 (MB-6), but can actually spread up to $5 \mathrm{~cm}$ below the SWI (winter and spring seasons). Below this suboxic layer (or anaerobic oxidant layer), the concentration of sulfate decreased and sulfides appeared around 3-4 cm below the SWI in May 2003 (Metzger et al., this issue).

\subsection{Mercury in the solid phase}


$\mathrm{HgT}_{\mathrm{P}}$ concentration distributions showed a steady increase with a depth from $1.7 \pm 0.3$ $\mathrm{nmol} \cdot \mathrm{g}^{-1}$ at the SWI to $2.3 \pm 0.5 \mathrm{nmol} \cdot \mathrm{g}^{-1} 130 \mathrm{~mm}$ below (Fig. 3). According to the dating by Schmidt et al. (this issue), the bottom of the cores $(130-140 \mathrm{~mm})$ is thought to shelter sediment deposited 50 years ago. Distributions were even variable within the perimeter of collection (core \#1, \#3 and \#4 collected in May 2003) and time of collection (cores taken in December 2001, August 2002 and May 2003). The concentration levels were several times higher $\left(1.9 \pm 0.3,2.1 \pm 0.2\right.$ and $2.0 \pm 0.3 \mathrm{nmol} \cdot \mathrm{g}^{-1}$ during MB-1, 3 and 5 respectively) than the accepted background values for unimpacted coastal sediments, usually lower than $0.5 \mathrm{nmol} \cdot \mathrm{g}^{-}$ 1 (Cossa et al., 1990). The same pattern was observed for other analyzed metals, and interpreted as the result of contamination over the last 100 years, which has decreased in the last few decades (Elbaz, personal communication). In addition, the unusual negative correlation $\left(\mathrm{r}^{2}=0.52\right)$ between $\operatorname{HgT}_{\mathrm{P}}$ and LOI attests an anthropic signature.

$\mathrm{MMHg}_{\mathrm{P}}$ ranged from 0.35 to $12.75 \mathrm{pmol} \cdot \mathrm{g}^{-1}$ (Fig. 4). Such levels were also found in sediments from the Seine estuary (Mikac et al., 1999), San Francisco Bay-Delta (Choe et al., 2004) or Long Island Sound (Hammerschmidt and Fitzgerald, 2004). Both the horizontal and vertical $\mathrm{MMHg}_{\mathrm{P}}$ distribution patterns contrasted with those of $\operatorname{HgT}_{\mathrm{P}}$. Except for core \#4, vertical distribution of $\mathrm{MMHg}_{\mathrm{P}}$ displayed a strong decreasing gradient within the first $30 \mathrm{~mm}$ (Fig. 4). The concentrations varied slightly or remained relatively constant further down the core. In addition, $\mathrm{MMHg}_{\mathrm{P}}$ profiles presented an overall horizontal increasing pattern with proximity to the ropes of the culture table which the oysters were attached to (from $1.2 \pm 0.5$ $\mathrm{pmol} \cdot \mathrm{g}^{-1}$ to $\left.8 \pm 2 \mathrm{pmol} \cdot \mathrm{g}^{-1}\right)$. When the average concentrations in each core were considered, there was found to be a significant positive relationship between MMHg and LOI $\left(r^{2}=0.71\right)$. The fraction of $\mathrm{HgT}_{\mathrm{P}}$ as $\mathrm{MMHg}_{\mathrm{P}}$ in marine and estuarine sediments is generally low $(<0.5 \%)$ (e.g., Bartlett et al., 1981, Benoit et al., 1998). In the Thau lagoon the ratios ranged from 0.02 to $0.80 \%$ averaging $0.24 \%$. The distribution of the methylated solid fraction was higher towards the SWI and decreased with depth.

\subsection{Mercury in the dissolved phase}

\subsubsection{Sediment core data (MB-5, May 2003)}

Even if dissolved oxygen (Dedieu et al., this volume), manganese and iron $(<0.45 \mu \mathrm{m})$ profiles revealed a sharp lateral heterogeneity of the sediment within a small perimeter $(<1$ $\mathrm{m})$, general patterns can be described. The range of the oxygen penetration depths was less than $4 \mathrm{~mm}$, and $\mathrm{Fe}_{\mathrm{D}}$ presence ranged from 10 to $70 \mathrm{~mm}$ in thickness, depending on the core, with concentrations between 10 and $200 \mu \mathrm{M}$ (Fig. 5). Except for Core \#1, the first centimeters 
below the SWI were mainly suboxic. In the deepest part of the cores, passing through the sulfide-accumulating zone (SAZ), iron was precipitated as sulfide even if low levels of dissolved FeS complex might have been present (Jézéquel et al., this volume).

The $\operatorname{HgT}_{\mathrm{D}}$ concentrations (15 to $85 \mathrm{pM}$ ) were found to vary widely from one core to the next (Fig. 6). Mean concentrations ( $30 \pm 15$ pM) were in the same order of magnitude as those reported for estuarine sediments (up to 50 pM) (Cossa and Gobeil, 2000; Sunderland et al., 2004). Except for Core \#1, the distributions of $\operatorname{HgT}_{\mathrm{D}}$ displayed a general trend of higher values close to the $\mathrm{Fe}_{\mathrm{D}}$ maximum (within the first $60 \mathrm{~mm}$ ) or to the $\mathrm{SAZ}$, which suggests a $\mathrm{Hg}$ mobilization associated with the solubilization of iron solid phases (oxides and sulfides). A slight increase in $\mathrm{HgT}_{\mathrm{D}}$ was observed with depth (Fig.6) below $100 \mathrm{~mm}$.

Despite the high variability from one core to another, $\mathrm{MMHg}_{\mathrm{D}}$ in pore water showed a pronounced subsurface maximum, typically at 5-40 $\mathrm{mm}$ below the surface. The maximum concentrations of $\mathrm{MMHg}_{\mathrm{D}}$ measured in subsurface sediment varied from 0.5 to $2.5 \mathrm{pM}$ and were consistent with $\mathrm{MMHg}_{\mathrm{D}}$ from other similar environments (e.g., Choe et al., 2004). The proportion of $\mathrm{HgT}$ as $\mathrm{MMHg}$ in the dissolved phase $\left(\mathrm{MMHg}_{\mathrm{D}} / \mathrm{HgT}_{\mathrm{D}}\right)$ in surface sediments (upper $40 \mathrm{~mm}$ ) was found to be 3-15\%. Core profiles exhibited another $\mathrm{MMHg}_{\mathrm{D}}$ maximum coincidental with or adjacent to the SAZ. Depending on the core, the $\mathrm{MMHg}_{\mathrm{D}}$ peak was 20$60 \mathrm{~mm}$ thick, with concentration maxima close to 1 pM (Fig. 6). As the oxygen penetration showed the redoxcline to be located within the first millimeters of the sediment (Dedieu et al., this volume), the lower $\mathrm{MMHg}_{\mathrm{D}}$ maximum (below $30 \mathrm{~mm}$ ) was clearly within anaerobic conditions.

\subsubsection{Peeper dialysis measurements (MB-6, June 2004)}

Peeper water displayed similar Hg distribution patterns as that obtained by pore water extraction in May 2003. High concentrations of $\mathrm{HgT}_{\mathrm{D}}$ and $\mathrm{MMHg}_{\mathrm{D}}$ were found $30 \mathrm{~mm}$ below the SWI (14 and 3.5 pM respectively, Fig. 7). Concentrations within the first $130 \mathrm{~mm}$ above the SWI (epibenthic water) were surprisingly high especially for $\mathrm{MMHg}_{\mathrm{D}}$ (up to $3.1 \mathrm{pM}$ ) compared to 0.03 to $0.09 \mathrm{pM}$ measured in oxic water at $50 \mathrm{~mm}$ above the SWI in May 2003. The methylated fraction of the $\operatorname{HgT}_{\mathrm{D}}$ attained $40 \%$ in sediments and $17 \%$ in epibenthic water.

The peepers provided comparative total sulfide $\left(\Sigma \mathrm{H}_{2} \mathrm{~S}\right)$ and $\mathrm{pH}$ distributions in pore and epibenthic water (Fig. 7). The $\mathrm{pH}$ profile covered 0.5 units from 7.5 (270 mm deep) to 8.0 (70 $\mathrm{mm}$ above the SWI). Just below the SWI the pH dropped by 0.23 with a gradient of -0.06 
unit $\mathrm{cm}^{-1}$. Pore water $\mathrm{pH}$ was higher towards the interface and decreased slowly with depth excluding a drop in the deeper sediments (from 210 to $270 \mathrm{~mm}$ ). $\Sigma \mathrm{H}_{2} \mathrm{~S}$ concentrations varied from $0.02 \mathrm{mM}$ at $10 \mathrm{~mm}$ above the SWI to $24.2 \mathrm{mM} 270 \mathrm{~mm}$ below. Perceptible $\mathrm{\Sigma H}_{2} \mathrm{~S}$ concentrations (> $10 \mu \mathrm{M})$ within epibenthic water suggested the occurrence of a hypoxic event in the water column. $\Sigma \mathrm{H}_{2} \mathrm{~S}$ concentrations also showed a linear gradient with depth $\left(r^{2}=0.99\right)$ within 210 first mm below the SWI. MMHg and $\Sigma \mathrm{H}_{2} \mathrm{~S}$ were positively correlated in epibenthic water $\left(r^{2}=0.79\right.$ up to $\left.110 \mathrm{~mm}\right)$ but negatively bound in pore water $\left(r^{2}=0.90\right.$ down to $150 \mathrm{~mm}$ ) (Fig. 8).

According to Benoit et al. (2003), the optima in methylation rate derive from the combination of the increase availability of $\mathrm{Hg}$ to the SRB coupled with a decreasing sulfate reduction rate. When plotted against $\Sigma \mathrm{H}_{2} \mathrm{~S}$, the dissolved methylated fraction gradient $\left(\delta\left(\mathrm{MMHg}_{\mathrm{D}} / \mathrm{HgT}_{\mathrm{D}}\right) / \delta\right.$ (position), a proxy of in situ methylation) exhibited two well-defined optima: a maximum at $1.9 \mathrm{mM}$ suggesting a production zone and a minimum at $11.9 \mathrm{mM}$ suggesting a removal processes These two concentrations correspond to the expected depths (30 and $130 \mathrm{~mm}$ respectively) for "endogenic" methylation and the precipitation of insoluble metacinnabar (HgS) or pyritization (e.g., Morse and Luther III, 1999).

\subsection{Water-solid partitioning of mercury}

In May 2003 (MB-5), despite a high spatial variability (Fig. 6), the $\mathrm{HgT}_{\mathrm{D}}$ distribution in pore water was characterized by two distinct patterns. In the deepest part of the cores, where iron is thought to precipitate as sulfide (Fig. 5), the distributions of $\operatorname{HgT}_{\mathrm{D}}$ and $\operatorname{HgT}_{\mathrm{P}}$ were parallel $\left(\left[\operatorname{HgT}_{D}\right]=14\left[\operatorname{HgT}_{P}\right]-8 ; r^{2}=0.53\right.$ and $\left.n=23\right)$. The $\operatorname{logKd} d_{H g T}$ below the SAZ were constant with depth $(4.92 \pm 0.14)$. This suggests that an equilibrium between solid and dissolved phases dominates the HgT distribution in the presence of sulfide (Fig. 9). Conversely, in the upper parts (between 20 and $70 \mathrm{~mm}$ depending on the core), with iron in the dissolved phase, $\operatorname{HgT}_{D}$ and $\operatorname{HgT}_{\mathrm{P}}$ distributions were mirror images of each other $\left(\left[\operatorname{HgT}_{\mathrm{D}}\right]=\right.$ -55[HgT $\mathrm{H}_{\mathrm{P}}+130 ; \mathrm{r}^{2}=0.52$ and $\left.\mathrm{n}=15\right)$, reflecting dissolution / desorption and precipitation /

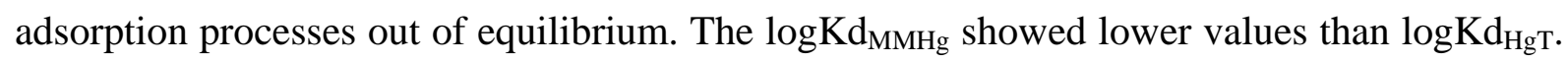
Wide variations of the partition coefficients for $\mathrm{MMHg}$ (from 2.96 to 4.63) were observed near the SWI and SAZ, which also suggest a non steady-state situation (Fig. 9).

The low concentrations of $\mathrm{HgT}_{\mathrm{D}}$ and $\mathrm{MMHg}_{\mathrm{D}}$ at the SWI (Fig. 7) suggest a removal process, which we construed to be due to the scavenging of dissolved mercury species on the superficial oxyhydroxides. The results of the selective dissolution of this mineral phase on two cores collected during the June 2004 are shown in figure 10. They revealed a surface 
enrichment in $\mathrm{Fe}_{\mathrm{Ox}}$ 4.6-2.1 $\mu \mathrm{mol} \cdot \mathrm{g}^{-1}$ and $\mathrm{Mn}_{\mathrm{Ox}}$ 0.19-0.14 $\mu \mathrm{mol} \cdot \mathrm{g}^{-1}$ in Cores \#1 and \#2 respectively. In addition, both exhibited high concentrations of $\mathrm{Fe}_{\mathrm{Ox}}$ and $\mathrm{Mn}_{\mathrm{Ox}}$ between 40 and $60 \mathrm{~mm}$, which may reflect a local in-depth injection of epibenthic water due to biological activity. Associated total mercury $\left(\mathrm{HgT}_{\mathrm{Ox}}\right)$ ranged from below the detection limit $(0.15$ $\mathrm{pmol} \cdot \mathrm{g}^{-1}$ ) to $3.6 \mathrm{pmol} \cdot \mathrm{g}^{-1}$. The vertical distributions of $\operatorname{HgT}_{\mathrm{Ox}}$ showed higher concentrations right next to the SWI and their decrease with depth. $\mathrm{HgT}_{\mathrm{Ox}}$ was positively related with $\mathrm{Fe}_{\mathrm{Ox}}$ and $\mathrm{Mn}_{\mathrm{Ox}}$ in Core \#1 ( $\mathrm{r}^{2}=0.27$ and 0.91 respectively) and Core \#2 ( $\mathrm{r}^{2}=0.68$ and 0.64 respectively). As for $\mathrm{HgT}_{\mathrm{Ox}}$, associated methylmercury ( $\mathrm{MMHg}_{\mathrm{Ox}}$ ) distributions accounted for an exponential decrease with depth in both cores. The surface maximum (0.68 and 0.24 $\mathrm{pmol} \cdot \mathrm{g}^{-1}$, respectively for Cores \#1 and \#2) preceded a drop in concentration within the 25 first millimeters reaching below detection limit values (0.05 pmol.g $\left.{ }^{-1}\right)$ (Fig. 10). MMHgox displayed substantial and positive correlations with $\mathrm{Fe}_{\mathrm{Ox}}$ and $\mathrm{Mn}_{\mathrm{Ox}}$ within the first $40 \mathrm{~mm}$ in Core \#1 ( $r^{2}=0.44$ and 0.99 respectively) and \#2 $\left(r^{2}=0.99\right.$ and 0.99 respectively). Total and methylmercury in the oxyhydroxides stood respectively at 0.2 and $4 \%$ of their relative total species. The methylated fraction (MMHgox $/ \mathrm{HgT}_{\mathrm{Ox}}$ ) attained 19 and $12 \%$ in Cores \#1 and \#2 respectively. These results are in general agreement with the model that $\mathrm{Fe}_{\mathrm{Ox}}$ and $\mathrm{Mn}_{\mathrm{Ox}}$ bind MMHg to a large degree in surface and suspended sediments (e.g., Cossa et al., 1996; Laurier et al., 2003).

\section{Discussion}

\subsection{Speciation and distribution of mercury in sediments}

The gradual decrease from high $\operatorname{HgT}_{\mathrm{P}}$ concentration at depth to surface sediment of (Fig. 3) suggests a slow down in mercury inputs and their efficient burial in the sediment in this location of the Thau lagoon. According to Schmidt et al. (this issue) our $140 \mathrm{~mm}$ long cores correspond to the sedimentary deposition over the last 50 years. The analysis of a dated $40 \mathrm{~cm}$ long core indicated that other metals with an anthropic signature (e.g., $\mathrm{Cd}, \mathrm{Pb}, \mathrm{Cu}$ and Zn) also show steady increasing concentrations from the SWI to $100 \mathrm{~mm}$ in depth and exhibited maximal concentrations in strata corresponding to the 1950-1970 period (Elbaz, personal communication). In addition, the negative correlation observed between $\operatorname{HgT}_{\mathrm{P}}$ and LOI content ruled out any significant effect of OM diagenesis on the Hg distribution in the sediment. Thus, it is most likely that the observed distributions of $\mathrm{Hg}$ in the solid phase of the sediment reflect a decrease in mercury contamination in the Thau lagoon over the halfcentury. 
Two successive distribution patterns can be distinguished on the basis of the comparison of the total mercury concentration in dissolved and particulate phases. Below the SAZ where Fe and Mn are thought to precipitate as sulfide or carbonate, the distributions of $\mathrm{HgT}_{\mathrm{P}}$ and $\mathrm{HgT}_{\mathrm{D}}$ were parallel. Conversely, in the upper parts of the core, where Fe and $\mathrm{Mn}$ are present in the dissolved phase, $\operatorname{HgT}_{\mathrm{P}}$ and $\mathrm{HgT}_{\mathrm{D}}$ varied as mirror images of each other (Fig. 3 and 6). These features suggest that equilibrium between phases exists in the deepest anoxic part of the cores. It can be thought that the solid phase (e.g., HgS, iron monosulfur or pyrite) controls the dissolved mercury concentrations through the so-called pyritization process (e.g., Huerta-Diaz and Morse, 1992; Morse and Luther III, 1999). Above this layer, where suboxic conditions prevail, the solid (sulfides, oxides and $\mathrm{OM}$ ) is a source for $\operatorname{HgT}_{\mathrm{D}}$ in the pore water. Its dissolution provides HgT in the dissolved phase.

The mean feature in the MMHg vertical profiles is the occurrence of maximum concentrations in the vicinity of the SWI both in the solid and in pore water (Cores \#1, \#2 and \#3, Fig. 4 and 6). Although $\mathrm{MMHg}_{\mathrm{P}}$ increased towards the surface in Cores \#1 to \#3, the pore water concentrations decreased at the immediate interface in May 2003 (except Core \#1) and June 2003 peeper profiles (Fig. 7). A subsurface peak of $\mathrm{MMHg}_{\mathrm{D}}$, close to the SAZ, is also noticeable in Cores \#3 and \#4. Depending on the core, it accounted for less than $30 \%$ of the total amount of $\mathrm{MMHg}_{\mathrm{D}}$ contained in the $130 \mathrm{~mm}$ long profile while the main peak, close to the SWI, reached $72 \%$ and averaged of $57 \pm 10 \%$. This lesser $\mathrm{MMHg}_{\mathrm{D}}$ maxima, within the SAZ, suggests in situ methylation by sulfate reducing bacteria (SRB). The main (sometimes dual) $\mathrm{MMHg}_{\mathrm{D}}$ peak at the sediment-water interface suggests (i) a possible additional “exogen” source attributable to active MMHg mobilization from the material settling from the water column and incorporated into the nepheloid layer, or (ii) that $\mathrm{MMHg}_{\mathrm{D}}$ diffusing from below is trapped by the very top of the sediment surface layer and does not contribute substantially to the near-bottom concentrations. Results from June 2004, where very high $\mathrm{MMHg}_{\mathrm{D}}$ concentrations were found in the epibenthic water (Fig. 7), lend support to the idea that peeper equilibration during an 8 day period might have recorded transient effluxes of both $\mathrm{MMHg}_{\mathrm{D}}$ and sulfides from the surficial oxide layer. However, the significant correlation between $\mathrm{MMHg}_{\mathrm{D}}$ and $\Sigma \mathrm{H}_{2} \mathrm{~S}$ in epibenthic water $\left(\mathrm{r}^{2}=0.79\right.$ up to $\left.110 \mathrm{~mm}\right)$ and the results of Montperrus et al. (this issue) seem to privilege the in situ methylation hypothesis. The bulge shape of the $\mathrm{MMHg}_{\mathrm{D}}$ versus $\Sigma \mathrm{H}_{2} \mathrm{~S}$ relation (Fig. 8) suggests an optimum sulfide concentration favoring mercury methylation (Fig. 8), which is consistent with the hypothesis of neutral Hg- 
S complexes controlling the bioavailability of inorganic mercury for SRB methylation (Benoit et al., 2001 and 2003).

\subsection{Mercury cycling in the vicinity of the SWI}

Centimetric scale $\mathrm{pH}$ profiles, $\Sigma \mathrm{H}_{2} \mathrm{~S}, \mathrm{HgT}_{\mathrm{D}}$ and $\mathrm{MMHg}_{\mathrm{D}}$ concentration profiles were provided throughout the SWI by means of classic peeper measurements (Fig. 7). Most of the pore water $\mathrm{MMHg}_{\mathrm{D}}$ (about $83 \%$ of the measured amount, i.e., a $300 \mathrm{~mm}$ column) was found in the upper 30-90 mm of the sediment. Positive correlations between $\mathrm{HgT}_{\mathrm{D}}$ and $\mathrm{MMHg}_{\mathrm{D}}$ were found in pore and epibenthic waters $\left(\left[\mathrm{MMHg}_{\mathrm{D}}\right]=0.25\left[\mathrm{HgT}_{\mathrm{D}}\right]+0.35 ; \mathrm{r}^{2}=0.90\right.$ for sediment and $\left[\mathrm{MMHg}_{\mathrm{D}}\right]=0.07\left[\mathrm{HgT}_{\mathrm{D}}\right]+0.66 ; \mathrm{r}^{2}=0.45$ for the epibenthic water. A comparison of the slope values calculated for pore and epibenthic waters, suggests that $\mathrm{MMHg}_{\mathrm{D}}$ in pore water is more significantly related to $\operatorname{HgT}_{\mathrm{D}}$ than in the deep water column where different mercury speciation or physical processes (diffusion/advection) may dominate. Apart from this enriched phase of the sediment, $\mathrm{MMHg}_{\mathrm{D}}$ in pore water presented a negative correlation with $\Sigma \mathrm{H}_{2} \mathrm{~S}\left(\mathrm{r}^{2}=0.96\right)$ and a positive one with $\mathrm{pH}\left(\mathrm{r}^{2}=0.89\right)$. These features suggest (i) an inhibition of $\mathrm{Hg}$ methylation by pore water sulfide beginning at around $10 \mu \mathrm{M}$, in accordance with Benoit et al. (2001) and (ii) the release of $\mathrm{MMHg}$ in pore water through the anaerobic degradation of OM.

High values of $\mathrm{MMHg}_{\mathrm{D}}$ concentrations (2.5 pM) and methylated percentage (17 \%) in epibenthic water suggest that during hypoxic events mercury methylation can occur in the first centimeters above SWI (Fig. 7). In comparison, mean $\mathrm{MMHg}_{\mathrm{D}}$ concentrations in the whole water column (Fig. 2) and subsurface pore water were only 0.3 and $1.5 \mathrm{pM}$ respectively. Under hypoxic conditions, in spite of trapping by the sediment surface layer, correlation with sulfides may also suggest a simultaneous mobilization of $\mathrm{MMHg}_{\mathrm{D}}$ and sulfide at the SWI. Thus, as previously mentioned, both mobilization and methylation might be collocated at the SWI.

The precipitation and dissolution of $\mathrm{Fe}_{\mathrm{Ox}}$ and $\mathrm{Mn}_{\mathrm{Ox}}$ (and/or sulfides) emerged as relevant processes in sediment-water distributions of Hg species (Bothner et al., 1980; Gobeil and Cossa, 1993, Gagnon et al., 1997). $\mathrm{HgT}_{\mathrm{D}}$ and $\mathrm{MMHg}_{\mathrm{D}}$ in the pore water displayed low concentrations within the $\mathrm{HgT}_{\mathrm{Ox}}$ and $\mathrm{MMHg}_{\mathrm{Ox}}$ surface maxima suggesting a scavenging of the total and methylmercury (Fig. 7). Despite this fraction being a minor part of the total and methylated mercury (0.2 and $4 \%$ respectively), high Kd values at the SWI calculated from the data of figures 7 and 9 emphasize the $\mathrm{Hg}$ enrichment of the amorphous oxyhydroxides fraction (Table 2). This oxide barrier effect was clearly displayed just below the SWI 
(between 0 and $20 \mathrm{~mm}$ ) but could have varied in depth with oxygen penetration or diverse redox changes. The retention processes were confirmed by the positive correlations between $\mathrm{HgT}_{\mathrm{Ox}}$ or $\mathrm{MMHg}_{\mathrm{Ox}}$ and $\mathrm{Fe}_{\mathrm{Ox}}$ or $\mathrm{Mn}_{\mathrm{Ox}}$. In comparison with $\mathrm{Fe}$, Mn oxyhydroxides appear to be the preferential sequestering agent for MMHg $\left(2.7 \pm 1.3 \mu \mathrm{mol}_{\mathrm{MMHg}} \cdot \mathrm{mol}_{\mathrm{Mn}}{ }^{-1}\right.$ vs $0.14 \pm 0.03$ $\mu \mathrm{mol}_{\mathrm{MMHg}} \cdot \mathrm{mol}_{\mathrm{Fe}}{ }^{-1}$ ). The concentrations of $\mathrm{HgT}$ within the $\mathrm{Mn}_{\mathrm{Ox}}$ and $\mathrm{Fe}_{\mathrm{Ox}}$ were respectively $16 \pm 3 \mu \mathrm{mol}_{\mathrm{Hg}} \cdot \mathrm{mol}_{\mathrm{Mn}}{ }^{-1}$ and $0.81 \pm 0.08 \mu \mathrm{mol}_{\mathrm{Hg}} \cdot \mathrm{mol}_{\mathrm{Fe}}{ }^{-1}$. Significant correlations between total and methylmercury in the oxyhydroxides $\left(r^{2}=0.92\right.$ and $r^{2}=0.61$ with regard to Cores $\# 1$ and \#2) in surface sediments (0 to $40 \mathrm{~mm}$ ) coupled to comparable Kd values showed that HgT and MMHg were similarly scavenged onto the amorphous oxyhydroxides fraction.

\subsection{Assessing the diffusive mercury fluxes}

Based on the dissolved mercury gradient at the SWI, it was possible to calculate an average molecular diffusion flux according to Fick's first law of diffusion. The average diffusive fluxes calculated for $\mathrm{MMHg}_{\mathrm{D}}$ as $\mathrm{MMHgCl}$ and $\mathrm{HgT}_{\mathrm{D}}$ as $\mathrm{HgCl}_{4}{ }^{2-}$ during MB-5 were estimated to be $4 \pm 2$ and $40 \pm 15 \mathrm{pmol} \mathrm{m}^{-2} \mathrm{~d}^{-1}$ respectively. In June 2004, as a signature of the hypoxic event, the two classic peepers provided lower and even reverse fluxes for $\operatorname{HgT}_{\mathrm{D}}(-$ $20 \pm 5$ pmol m $\left.\mathrm{m}^{-2} \mathrm{~d}^{-1}\right)$ and $\mathrm{MMHg}_{\mathrm{D}}\left(1.5 \pm 0.5\right.$ and $\left.-1.5 \pm 0.5 \mathrm{pmol} \mathrm{m}^{-2} \mathrm{~d}^{-1}\right)$. All these flux calculations are less than those reported for the lower St. Lawrence Estuary (Gobeil and Cossa, 1993), Lavaca Bay (Gill et al., 1999) but closer to those from the San Francisco BayDelta (Choe et al., 2004). Our estimates are almost two orders of magnitude lower than the fluxes calculated using benthic chambers in the Thau lagoon (Point et al., this volume). Large discrepancies between diffusive and benthic chambers flux estimates have already been reported for the Gulf of Trieste (Covelli et al., 1999) and the San Fransico Bay (Choe et al., 2004). As a matter of fact, elevated sulfide concentrations scavenging on $\mathrm{Fe}$ and $\mathrm{Mn}$ oxyhydroxides (or/and on sulfides) or rough complexation with OM at the SWI support lower in situ diffusive fluxes.

Lastly, in order to evaluate the impact of methylmercury fluxes from the sediment on cultured oysters, it is assumed that the C5 conditions can be extrapolated to a reference area of $5 \mathrm{~km}^{2}$. This corresponds to the surface area of the northern oyster culture tables (Fig. 1). Calculations were performed for a 3-month period, the highly productive period (MayAugust) when the methylation is thought to be most active. Assuming that the May 2003 situation was representative of this period, the amounts of $\mathrm{HgT}_{\mathrm{D}}$ and $\mathrm{MMHg}_{\mathrm{D}}$ exported from the C5 sediment reference area via diffusive fluxes are estimated to be $20 \pm 5$ and $2 \pm 1 \mathrm{mmol}$ respectively. However, since high temporal and spatial variability, especially for $\mathrm{MMHg}_{\mathrm{D}}$, 
must be considered as significant sources of error, these mass calculations should be considered as rough estimations. Reverse fluxes (from water column to sediment) and epibenthic water methylation characterized the June 2004 hypoxic event. Considering that most of the epibenthic $\mathrm{MMHg}_{\mathrm{D}}$ (in excess of the $\mathrm{MMHg}_{\mathrm{D}}$ in the water column) originated from in situ methylation, it could be estimated the amount produced during the hypoxic event is $1.5 \pm 0.5 \mathrm{mmol}$ for the same reference area. These calculations suggest that during one hypoxic event the injected $\mathrm{MMHg}_{\mathrm{D}}$ amount in the water column is similar to that resulting from the diffusive flux from the sediment. On the other hand, the reverse $\mathrm{MMHg}_{\mathrm{D}}$ flux to the sediment during June 2004 accounted only for $0.25 \mathrm{mmol}$, i.e., $16 \%$ of the epibenthic methylated amount and $12 \%$ of the 3-month period efflux to the water column.

Mollusks from the Thau lagoon region exhibited relatively high total mercury $\left(0.7 \pm 0.4 \mathrm{nmol} \cdot \mathrm{g}^{-1}\right)$ and $\mathrm{MMHg}\left(0.5 \pm 0.3 \mathrm{nmol} \cdot \mathrm{g}^{-1}\right)$ concentrations compared to the means from the French coasts (Claisse et al., 2001). The $5 \mathrm{~km}^{2}$ reference area corresponds approximately to one third of the cultivated shellfish area in the lagoon, which annually produces 20,000 tons of oysters. As a result, the mercury uptake by oyster from the water column can be calculated as $50 \pm 35$ and $35 \pm 25 \mathrm{mmol} \mathrm{a}^{-1}$ for HgT and MMHg respectively. These figures are more than twice and fifteen times higher than the diffusive fluxes calculated for HgT and MMHg during the warm 3 month period. Ultimately, the relative importance of the sediment as a source for MMHg accumulation in shellfish of the Thau lagoon cannot be firmly assessed. Other sources of methylated mercury (river and effluents inputs, water column methylation, atmosphere, etc.) need to be explored.

\section{Summary and Conclusion}

1. The mercury concentration level and distributions in the solid phase of the sediment cores suggest an anthropogenic influence in decline over the last 50 years.

2. The total mercury partition between the solid and the dissolved phases suggests that (i) $\operatorname{HgT}_{\mathrm{D}}$ and $\operatorname{HgT}_{\mathrm{P}}$ are in equilibrium in deep parts of the cores when iron monosulfur or pyrite were present, and that (ii) during the dissolution of iron sulfides or/and oxides, the solid was a source for $\operatorname{HgT}_{\mathrm{D}}$ in pore water.

3. The bimodal distribution of the dissolved MMHg implies various sources. While the peak within the sulfide-accumulating zone indicates an in situ formation by sulfate reducing bacteria, the peak of concentrations approaching the sediment water interface suggests various 
explanations: (i) a mobilization of MMHg associated with the particles from the water column occurring during their degradation, (ii) a net methylation in the epibenthic layer and/or (iii) the relict of a transient efflux of $\mathrm{MMHg}_{\mathrm{D}}$ from below. This suggests that the localization of MMHg production under or below the SWI reflects the up and down movements of the redox barrier resulting from the stratification and the OM fluxes in the water column. The observed relationship between MMHg and sulfide supports the neutral $\mathrm{Hg}$ sulfide complexes hypothesis (Benoit et al., 1999, 2001, 2003).

4. High mercury and methylmercury within the amorphous oxyhydroxides fraction ( $\mathrm{HgT}_{\mathrm{Ox}}$ and $\mathrm{MMHg}_{\mathrm{Ox}}$ ) coupled to low ambient $\mathrm{HgT}_{\mathrm{D}}$ and $\mathrm{MMHg}_{\mathrm{D}}$ concentrations indicate that the amorphous oxyhydroxides ( $\mathrm{Fe}_{\mathrm{Ox}}$ and especially $\mathrm{Mn}_{\mathrm{Ox}}$ ) play a major role in controlling total and methylmercury mobility throughout the SWI. The significant positive correlations between $\mathrm{MMHg}_{\mathrm{Ox}}$ and $\mathrm{HgT}_{\mathrm{Ox}}$ or $\mathrm{MMHg}_{\mathrm{D}}$ and $\mathrm{HgT}_{\mathrm{D}}$ confirmed that MMHg distribution in superficial sediments is closely related to HgT. Finally, simultaneous factors such as $\Sigma \mathrm{H}_{2} \mathrm{~S}$, $\mathrm{pH}$, and $\mathrm{OM}$ appear to be of substantial importance in methylmercury partitioning and mobilization.

5. Diffusive fluxes of HgT and MMHg from sediment to the water column for the warm period were estimated to be $40 \pm 15$ and $4 \pm 2 \mathrm{pmol} \mathrm{m}^{-2} \mathrm{~d}^{-1}$ respectively. These diffusive fluxes are low compared to those obtained using benthic chambers (Point et al., this volume), and their magnitude greatly depends of the evolution of the redox state of the SWI. Consequently, the relative importance of the sediment as a source for MMHg accumulation in shellfish of the Thau lagoon cannot be firmly assessed. Other sources of methylated mercury need to be explored.

\section{Acknowledgment}

This research is a part of the MICROBENT project, within the PNEC program funded by IFREMER, INSUE and IRD. In addition, we are grateful to J. Bretaudeau-Sanjuan and K. Dedieu for their support in the equipment preparation, sampling and analyses, and J. Knoery for his helpful comments on the experimental design and results. Finally let us also thank Jean-Louis Guillou, Jean-Jacques Bourrand and Bruno Bombled for collecting the sediment cores and obtaining the interstitial pore water samples. 


\section{References}

Applin, K.R., Lasaga, A.C., 1984. The determination of $\mathrm{SO}_{4}{ }^{2-}, \mathrm{NaSO}_{4}{ }^{-}$, and $\mathrm{MgSO}_{4}{ }^{0}$ tracer diffusion coefficients and their applications to diagenetic flux calculations. Geochimica et Cosmochimica Acta 48, 2151-2162.

Bartlett, P.D., Craig, P.J., 1981. Total mercury and methyl mercury levels in British estuarine sediments. Water Research 15, 37-47.

Benoit, J.M., Gilmour, C.C., Mason, R.P., Riedel, G.S., Riedel, G.F., 1998. Behavior of mercury in the Patuxent River estuary. Biogeochemistry 40, 249-265.

Benoit, J.M., Mason, R.P., Gilmour, C.C., 1999. Estimation of mercury-sulfide speciation in sediment pore waters using octanol-water partitioning and implications for availability to methylating bacteria. Environmental Toxicology and Chemistry 18, 2138-2141.

Benoit, J.M., Gilmour, C.C., Mason, R.P., 2001. The influence of sulfides on solid-phase mercury bioavailability for methylation by pure cultures of Desulfobulbus propionicus. Environmental Science and Technology 35, 127-132.

Benoit, J.M., Gilmour, C.C., Heyes, A., Mason, R.P., Miller, C.L., 2003. Geochemical and Biological Controls over Methylmercury Production and Degradation in Aquatic Ecosystems. Chap. 19., pp. 262-297. In: Biogeochemistry of Environmentally Important Trace Elements. Cai, Y., Braids, O.C. (Eds.). ACS Symposium series 835. American Chemical Society, Washington, DC. 436p.

Benoit, J.M., Shull, D.H., Robinson, P., Ucran, L.R., Infaunal Burrow Densities and Sediment Monomethyl Mercury Distributions in Boston, Harbor, Massachusetts. Marine Chemistry in press.

Bloom, N.S. 1989. Determination of picogram levels of methylmercury by aqueous phase ethylation followed by cryogenic gas chromatography with cold vapour atomic fluorescence detection. Canadian Journal of Fisheries and Aquatic sciences 46, 1131-1140.

Bloom, N.S., Fitzgerald, W.F., 1998. Determination of volatile mercury species at picogram level by low temperature gas chromatography with cold-vapour atomic fluorescence detection. Analytica Chimica Acta 28, 151-161.

Bloom, N.S., Gill, G.A., Cappellino, S., Dobbs, C., Mcshea, L. Driscoll, C., Mason, R.P., Rudd, J. 1999. Speciation and Cycling of Mercury in Lavaca Bay, Texas, Sediments. Environmental science and Technology 33, 7-13. 
Bloom, N.S., Moretto, L.M., Scopece, P., Ugo, P. 2004. Seasonal cycling of mercury and monometyl mercury in the Venice Lagoon (Italy). Marine Chemistry 91, 85-99.

Bothner, M.H., Jahnke, R.A., Peterson, M.L., Carpentier, R., 1980. Rate of mercury loss from contaminated estuarine sediments. Geochimica et Cosmochimica Acta 44, 273-285.

Boudreau, B.P., 1996. Diffusive tortuosity on fine-grained unlithified sediments. Geochimica et Cosmochimica Acta 60, 3139-3142.

Calvario, J., Dutrieux, E., Gout, B., Guelorget, O., Perthuisot, J.-P., 1989. La macrofaune benthique des substrats meubles de l'étang de Thau (Hérault, France). Colloque anniversaire UOF, Paris.

Choe, K.-Y., Gill, G.A., Lehman, R.D., Han, S., 2004. Sediment-water exchange of total mercury and monomethyl mercury in the San Francisco Bay-Delta. Limnology and Oceanography 49, 1512-1527.

Claisse, D., Cossa, D., Bretaudeau_Sanjuan, J., Touchard, G., Bombled, B., 2001. Methylmercury in Molluscs Along the French Coast. Marine Pollution Bulletin 42, 329332.

Cossa, D., Thibaud, Y., Roméo, M., Gnassia-Barelli, M., 1990. Le mercure en milieu marin: Biogéochimie et écotoxicologie. Rapport scientifique et techniques de l'Ifremer №19. Edition Ifremer, Plouzané (France). 130 pp.

Cossa, D., Coquery, M., Gobeil, C., Martin, J.-M., 1996. Mercury Fluxes at the Ocean Margins. p. 229-247. In: Regional and Global Cycles of Mercury: Sources, Fluxes, and Mass Balances. Baeyens, W., Ebinghaus R., Vasiliev, O. (Eds.). Kluwer Academic Publishers, Dordrecht, The Netherlands.

Cossa, D., Gobeil, C., 2000. Mercury speciation in the Lower St. Lawrence estuary. Canadian Journal of Fisheries and Aquatic Sciences 57, 138-147.

Cossa, D., Coquery, M., Nakhlé, K., Claisse, D. 2002. Dosage du mercure total et du monomethylmercure dans les organismes et les sédiments marins. Méthodes d’analyse en milieu marin, Editions Ifremer, 27pp.; ISBN 2-84433-105-X.

Cossa, D., Averty, B., Bretaudeau, J., Sénard, A.S., 2003. Spéciation du mercure dissous dans les eaux marines. Méthodes d'analyse en milieu marin, Editions Ifremer, 27 pp.; ISBN 284433-125-4. 
Craig, P.J., Moreton, P.A., 1986. Total mercury, methyl mercury and sulphide levels in British estuarine sediments. Water Research 9, 1111-1118.

Dedieu, K., Thouzeau, G., Chavaud, L., Vlavier, J., Jean, F., Rabouille, C., 2005. Benthic $0_{2}$ distribution and dynamics in a lagoon ecosystem: in-situ microelectrodes study. Estuarine and Coastal Shelf Science, this issue.

Gagnon, C., Fisher, N.S., 1997. Bioavailability of Sediment-Bound Methyl and Inorganic Mercury to a Marine Bivalve. Environmental Science and Technology 31, 993-998.

Gagnon, C., Pelletier, E., Mucci, A., Fitzgerald, F.W., 1996. Diagenetic behavior of methylmercury in organic-rich coastal sediments. Limnology and Oceanography 41, 428434.

Gill, G.A., Bloom, N.S., Cappellino, S., Driscoll, C.T., Dobbs, C., McShea, L., Mason, R.P., Rudd, J.W., 1999. Sediment-Water Fluxes of Mercury in Lavaca Bay, Texas. Environmental Science and Technology 33, 663-669.

Gilmour, C.C., Henry, E.A., Mitchell, R., 1992. Sulfate Stimulation of Mercury Methylation in Freshwater Sediments. Environmental Science and Technology 26, 2281-2287.

Gilmour, C.C., Riedel, G.S., Ederington, M.C., Bell, J.T., Benoit, J.M., Gill, G.A., Stordal, M.C., 1998. Methylmercury concentrations and production rates across a trophic gradient in the northern Everglades. Biogeochemistry 40, 327-345.

Gobeil, C., Cossa, D., 1993. Mercury in the sediments and sediment pore waters in the Lawrentian Trough. Canadian journal of Fisheries and Aquatic Sciences 50, 1794-1800.

Guentzel, J.L., Powell, R.T., Landing, W.M., Mason, R.P., 1996. Mercury associated with colloidal material in an estuarine and an open-ocean environment. Marine Chemistry 55, 177-188.

Hammerschmidt, C.R., Fitzgerald, W.F., Lamborg, C.H., Balcom, P.H., Visscher, P.T., 2004. Biogeochemistry of methylmercury in sediments of Long Island Sound. Marine Chemistry 90, 31-52.

Huerta-Diaz, M.A., Morse, J.W., 1992. Pyritization of trace metals in anoxic marine sediments. Geochimica et Cosmochimica Acta 56, 2681-2702.

Jensen, S., Jernelöv, A. 1969. Biological Methylation of Mercury in Aquatic Organisms. Nature 223, 753-754. 
Jézéquel, D., Brayner, R., Metzger, E., Viollier, E., Prevot, F., Fiévet, F. 2005. Twodimensional determination of dissolved iron and sulfur species in marine sediment porewaters by thin-films based imaging, Thau lagoon (France). Estuarine Coastal Shelf Science, this issue.

King, J.K., Saunders, F.M., Lee, R.F., Jahnke, R.A., 1999. Coupling mercury methylation rates to sulfate reduction rates in marine sediments. Environmental Toxicology and Chemistry 18, 1362-1369.

Kostka, J. E., Luther, G. W. 1994. Partitioning and speciation of solid phase iron in saltmarsh sediments. Geochimica et Cosmochimica Acta 58, 1701-1710.

Kukulka, D. J., Gebhart, B., Mollendorf, J.C. 1987. Thermodynamic and transport properties of pure and saline water. Adv. Heat Transfer, 18, 325-363.

Laurier, F. J. G., Cossa, D., Gonzalez, J. L., Sarazin, G. 2003. Mercury transformations and exchanges in a high turbidity estuary: The role of organic matter and amorphous oxyhydroxides. Geochimica et Cosmochimica Acta 67, 3329-3345.

Leermarker, M. Galetti, S, de Galan, S. Brion, N, Baeyens, W. 2001. Mercury in the Souther North Sea and Sheldt Estuary. Marine Chemistry, 75, 229-248.

Li, Y.-H., Gregory, S., 1974. Diffusion of ions in seawater and in deep-sea sediments. Geochimica et Cosmochimica Acta 38, 703-714.

Liang, L., Horvat, M., Bloom, N.S. 1994. An improved speciation method for mercury by GC/CVAFS after aqueous phase ethylation and room temperature precollection. Talanta 41, 371-379.

Mason, R., Bloom, N., Cappellino, S., Gill, G., Benoit, J., Dobbs, C., 1998. Investigation of Porewater Sampling Methods for Mercury and Methylmercury. Environmental Science and Technology 32, 4031-4040.

Mason, R.P., Lawrence, A.L., 1999. Concentration, distribution, and bioavailability of mercury and methylmercury in sediments of Baltimore harbor and Chesapeake Bay, Maryland, USA. Environmental Toxicology and Chemistry 18, 2438-2447.

Mesnage, V., Ogier, S., Disnar, J.R., Lottier, N., Bally, G., Dedieu, K., Rabouille, C., Nutrient exchange dynamics at the water-sediment interface in a Mediterranean lagoon: influence of biodeposition by oyters farming. Estuarine and Coastal Shelf Science, this issue. 
Metzger, E., Simonucci, C., Jézéquel, C., Viollier, E., Sarazin, G., Prévot, F. 2005. Pore waters signature of biogeochemical processes in sediments of Thau lagoon (MICROBENT program). Estuarine Coastal Shelf Science, this issue.Mikac, N., Niessen, S., Ouddane, B., Wartel, M., 1999. Speciation of Mercury in Sediments of the Seine Estuary (France). Applied Organometallic Chemistry 13, 715-725.

Montperrus, M., Tessier, E., Point, D., Vidimova, K., Amouroux, D., Guyoneaud, R., Leynaert, A., Grall, J., Chauvaud, L., Thouzeau, G., Donard, O.F.X., The biogeochemistry of mercury at the sediment water interface in the Thau lagoon. 2. Measurements of mercury methylation potential in sediments and water and fate of methylmercury. Estuarine and Coastal Shelf Science, this issue.

Morse, J.W., Luther III, G.W., 1999. Chemical influences on trace metal-sulfide interactions in anoxic sediments. Geochimica et Cosmochimica Acta 63, 3373-3378.

Péna, G., Picot, B., 1991. Métaux traces dans les sédiments d'une lagune méditerranéenne: l'étang de Thau. Oceanologica Acta 14, 459-472.

Point, D., Montperrus, M., Tessier, E., Amouroux, D., Donard, O.F.X, Chauvaud, L., Thouzeau, G., Jean, F., Amice, E., Grall, J., Leynaert, A., Longphirt, S. Clavier, J. Benthic flux of metals and organometals at the sediment water interface using benthic chambers. Estuarine and Coastal Shelf Science, this issue.

RNO (Réseau national d’Observation de la qualité du milieu marin), 1998.Surveillance du milieu marin. Travaux du RNO. Ifremer et Ministère de l'Aménagement du Territoire et de l’Environnement. Edition 1998, Nantes, 58pp.

RNO (Réseau national d’Observation de la qualité du milieu marin), 1999.Surveillance du milieu marin. Travaux du RNO. Ifremer et Ministère de l'Aménagement du Territoire et de l’Environnement. Edition 1999, Nantes, 32 pp.

Schmidt, S., Jouanneau, J.M., Weber, O., Radakovich, O., Sediment dynamics of reworking at the sediment-water interface of the Thau lagoon (South France). From seasonal to century time scales using radiogenic and cosmogenic nuclides. Estuarine and Coastal Shelf Science, this issue.

Sunderland, E. M., Gobas, F. A. P. C., Heyes, A., Branfireun, B. A., Bayer, A. K., Cranston, R. E., Parsons, M. B., 2004. Speciation and bioavailability of mercury in well-mixed estuarine sediments. Marine Chemistry, 90, 91-105. 


\section{Tables captions}

\begin{tabular}{|l|c|c|c|}
\hline Campaign & Date & Type of samples & Mercury measurements \\
\hline MB-1 & December 2001 & $\begin{array}{c}\text { Water column, } \\
\text { Sediment core }\end{array}$ & $\begin{array}{c}\text { HgT }_{\mathrm{D}}, \mathrm{HgR}_{\mathrm{D}}, \mathrm{DGM}, \\
\mathrm{MMHg}_{\mathrm{D}}, \mathrm{HgT}_{\mathrm{P}}\end{array}$ \\
\hline MB-3 & August 2002 & $\begin{array}{l}\text { Water column, } \\
\text { Sediment core }\end{array}$ & $\begin{array}{c}\mathrm{HgT}_{\mathrm{D}}, \mathrm{HgR}_{\mathrm{D}}, \mathrm{DGM}, \\
\mathrm{MHHg}_{\mathrm{D}}, \mathrm{HgT}_{\mathrm{P}}\end{array}$ \\
\hline MB-5 & May 2003 & $\begin{array}{c}\text { Sediment core (pore } \\
\text { water extraction) }\end{array}$ & HgT $_{\mathrm{D}}, \mathrm{MMHg}_{\mathrm{D}}, \mathrm{HgT}_{\mathrm{P}}$ \\
\hline MB-6 & June 2004 & $\begin{array}{c}\text { Sediment core (pore } \\
\text { water extraction and } \\
\text { Peeper) }\end{array}$ & $\mathrm{HgT}_{\mathrm{D}}, \mathrm{MMHg}_{\mathrm{D}}, \mathrm{HgT}_{\mathrm{P}}$ \\
\hline
\end{tabular}

Table 1. Summary of the different sampling campaigns. 


\begin{tabular}{|l|c|c|}
\hline & $\operatorname{logKd} d_{\mathrm{HgT}}$ & $\operatorname{logKd} \mathrm{MMHg}$ \\
\hline Total solid & 4.79 & 3.69 \\
\hline $\mathrm{Fe}_{\mathrm{ox}}$ & 6.30 & 6.40 \\
\hline $\mathrm{Mn}_{\mathrm{ox}}$ & 7.61 & 7.73 \\
\hline
\end{tabular}

Table 2. Partition coefficient for total and methylmercury in surface sediment $(0-20 \mathrm{~mm})$. "Total soild" reefers to the bulk sediment, " $\mathrm{Fe}_{\mathrm{ox}}$ " and " $\mathrm{Mn}_{\mathrm{ox}}$ " to the oxyhydroxide fractions 


\section{Figure captions}

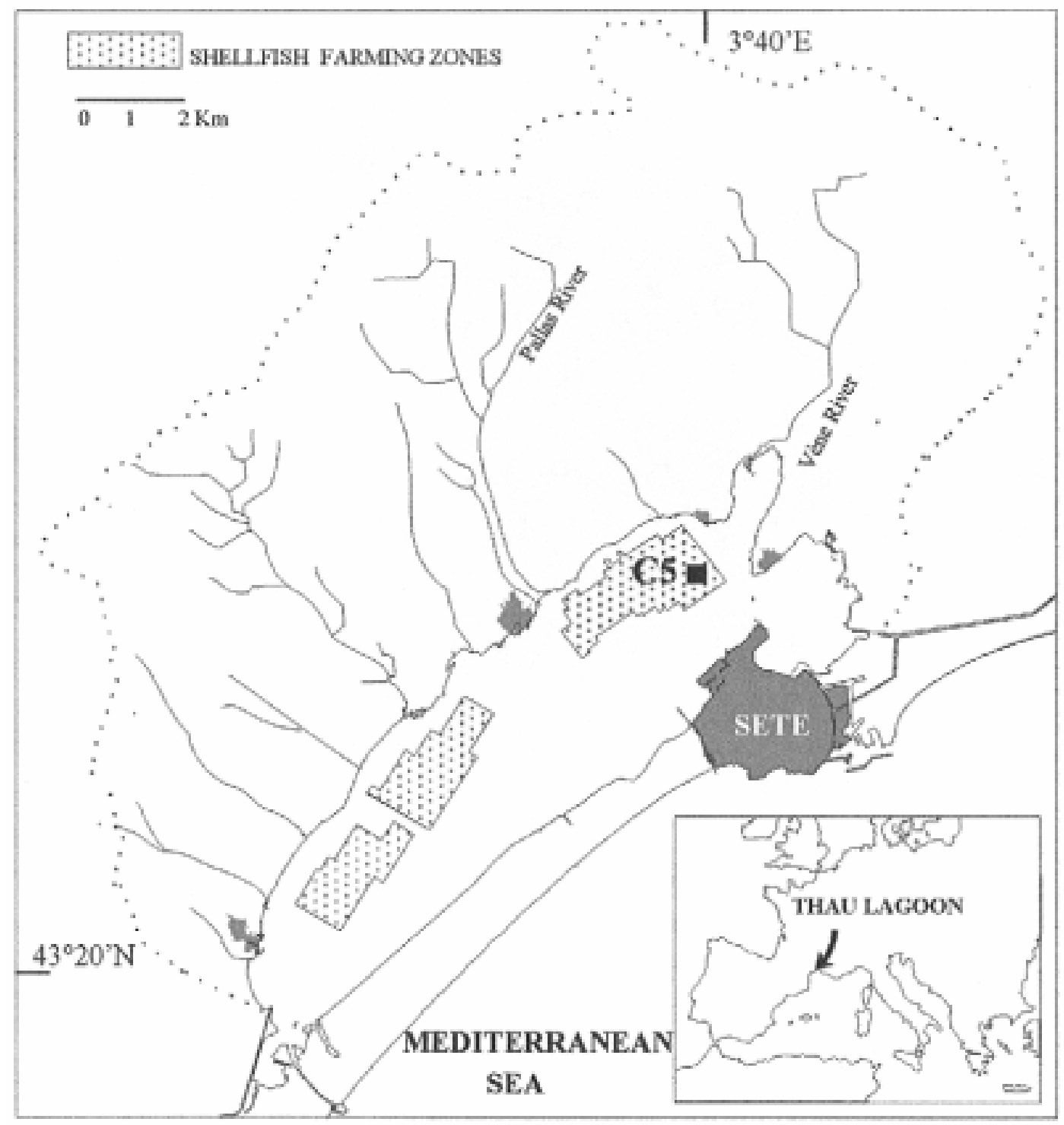

Figure 1. Map of the Thau lagoon showing the location of the C5 sampling station. Oyster culture tables are indicated by the light gray color. 


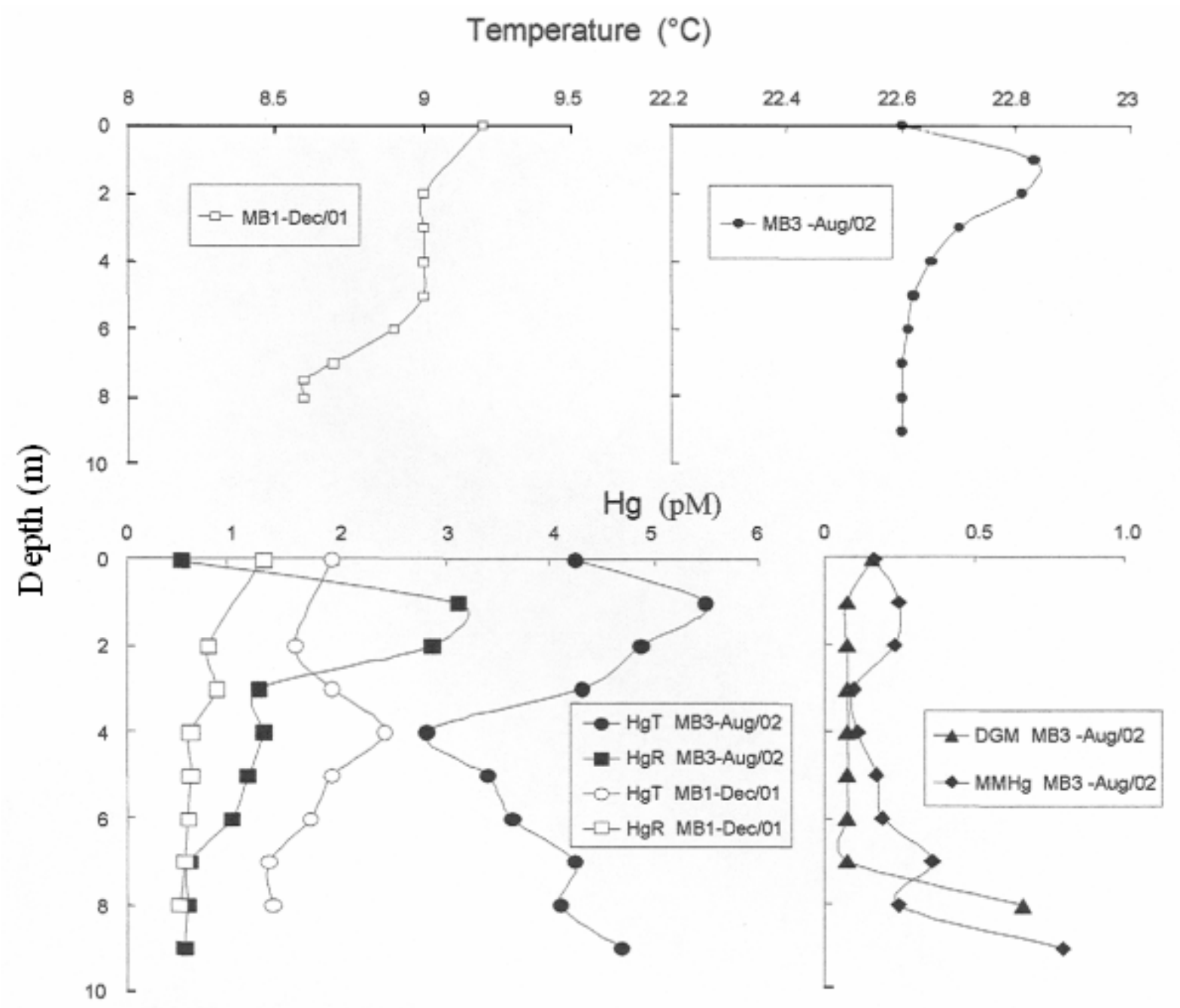

Figure 2. Vertical profiles of temperature and various mercury species at the C5 station. Samples were collected during MB-1 (December 2001) and MB-3 (August 2002) cruises. HgT: Total mercury, HgR: Reactive mercury (easily reducible mercury), DGM: Dissolved gaseous mercury and MMHg: Monomethylmercury. Open circles and squares reefer to samples filtrated on hydrophilic $0.45 \mu \mathrm{m}$ Teflon membrane, and filled ones to the non-filtrated water samples. 


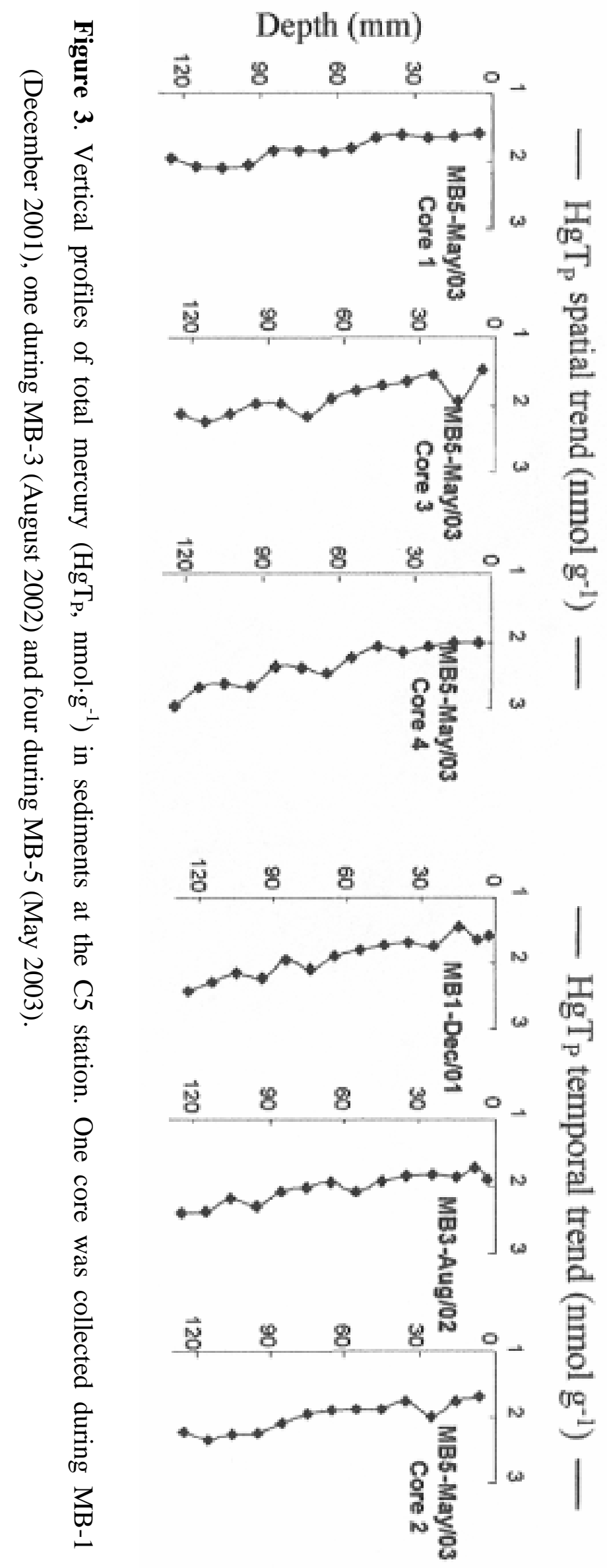




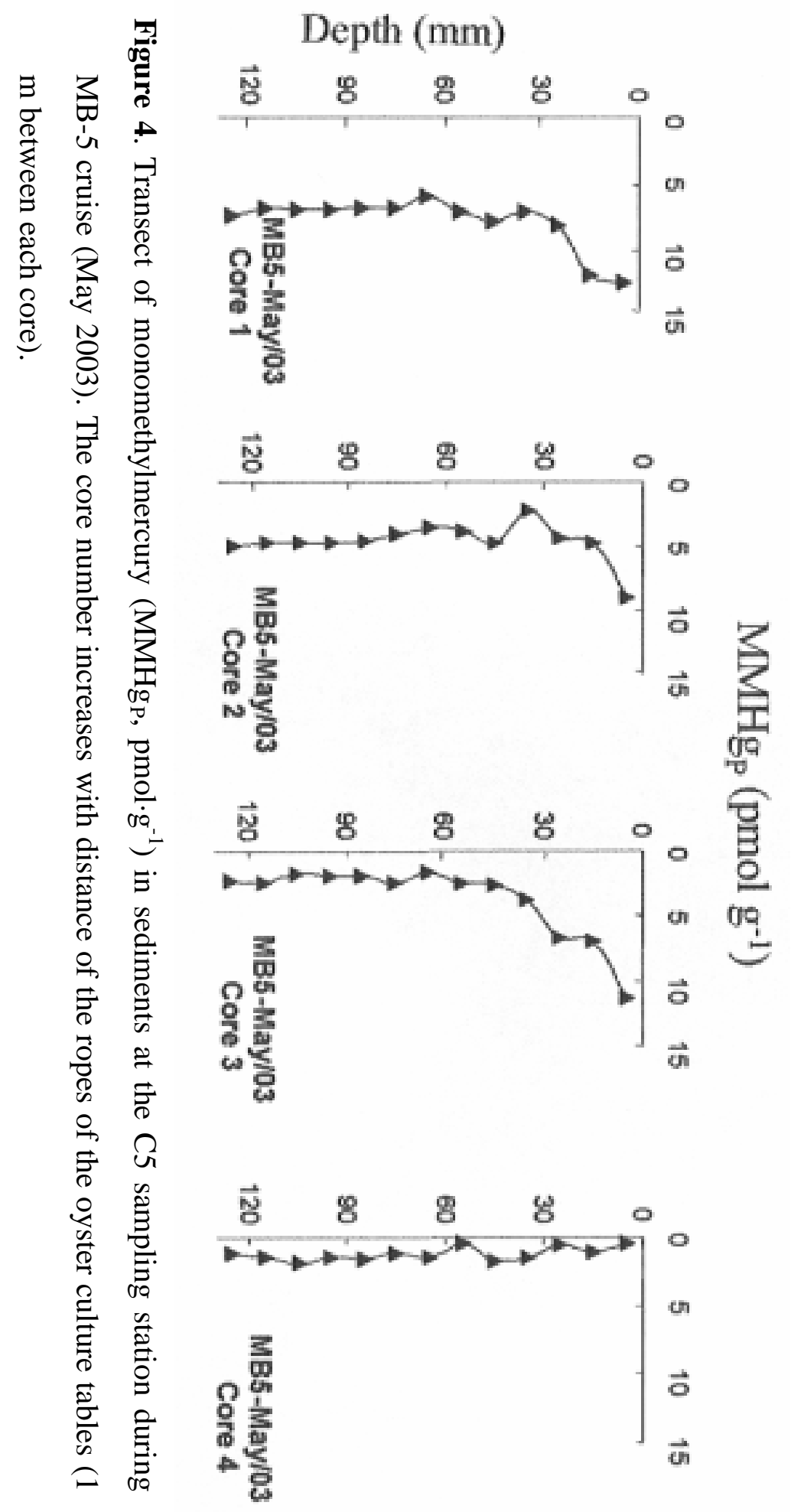




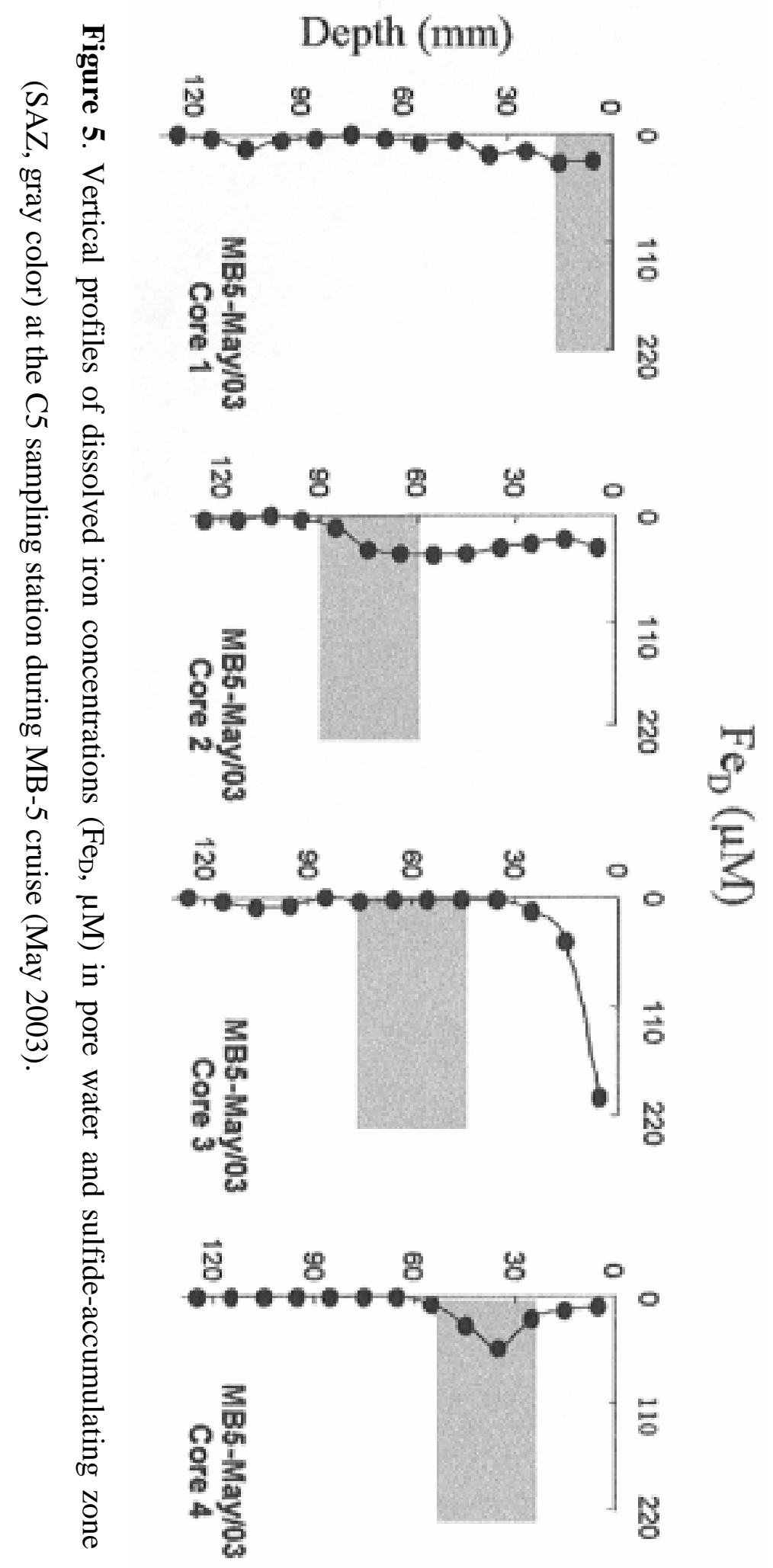




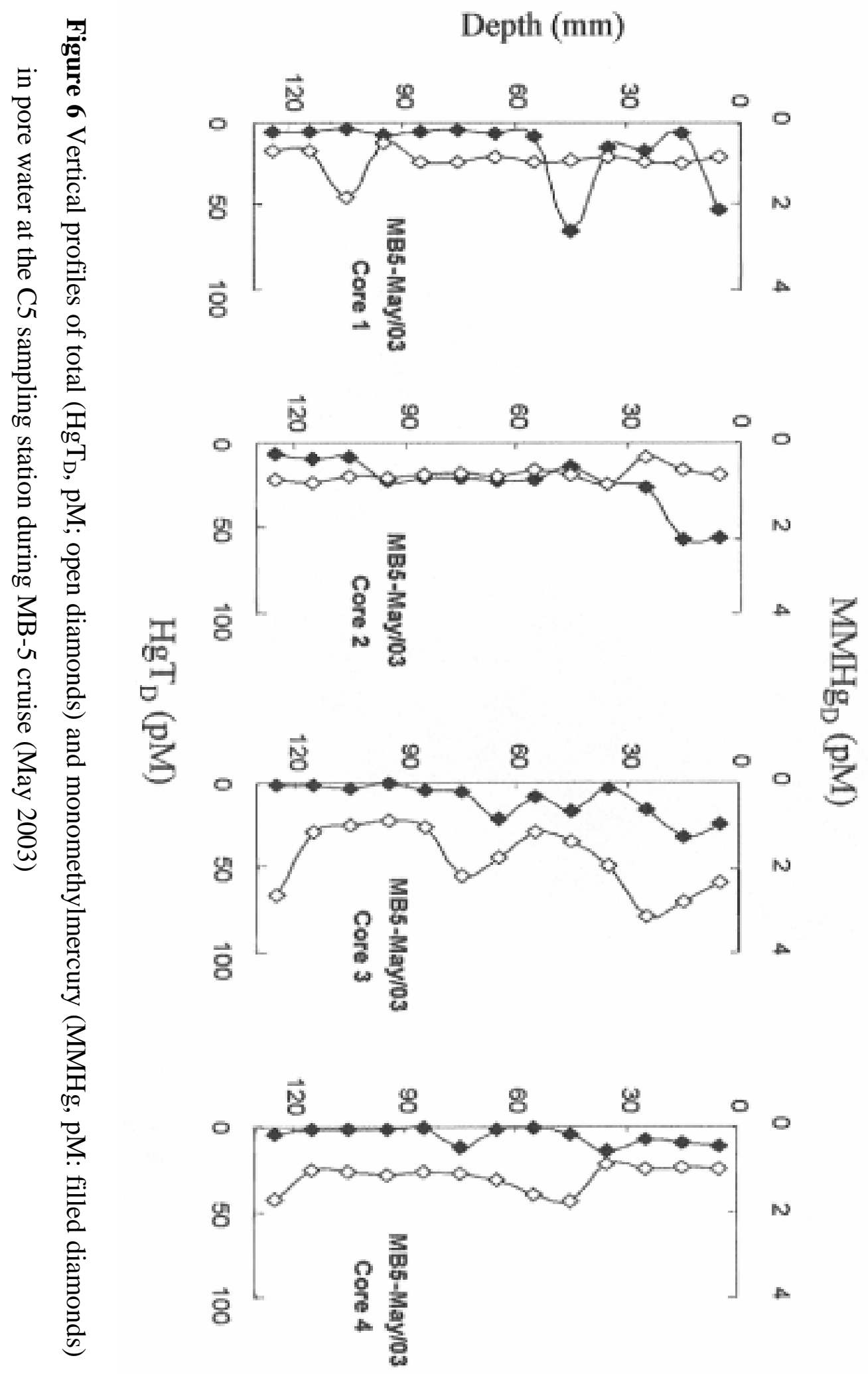




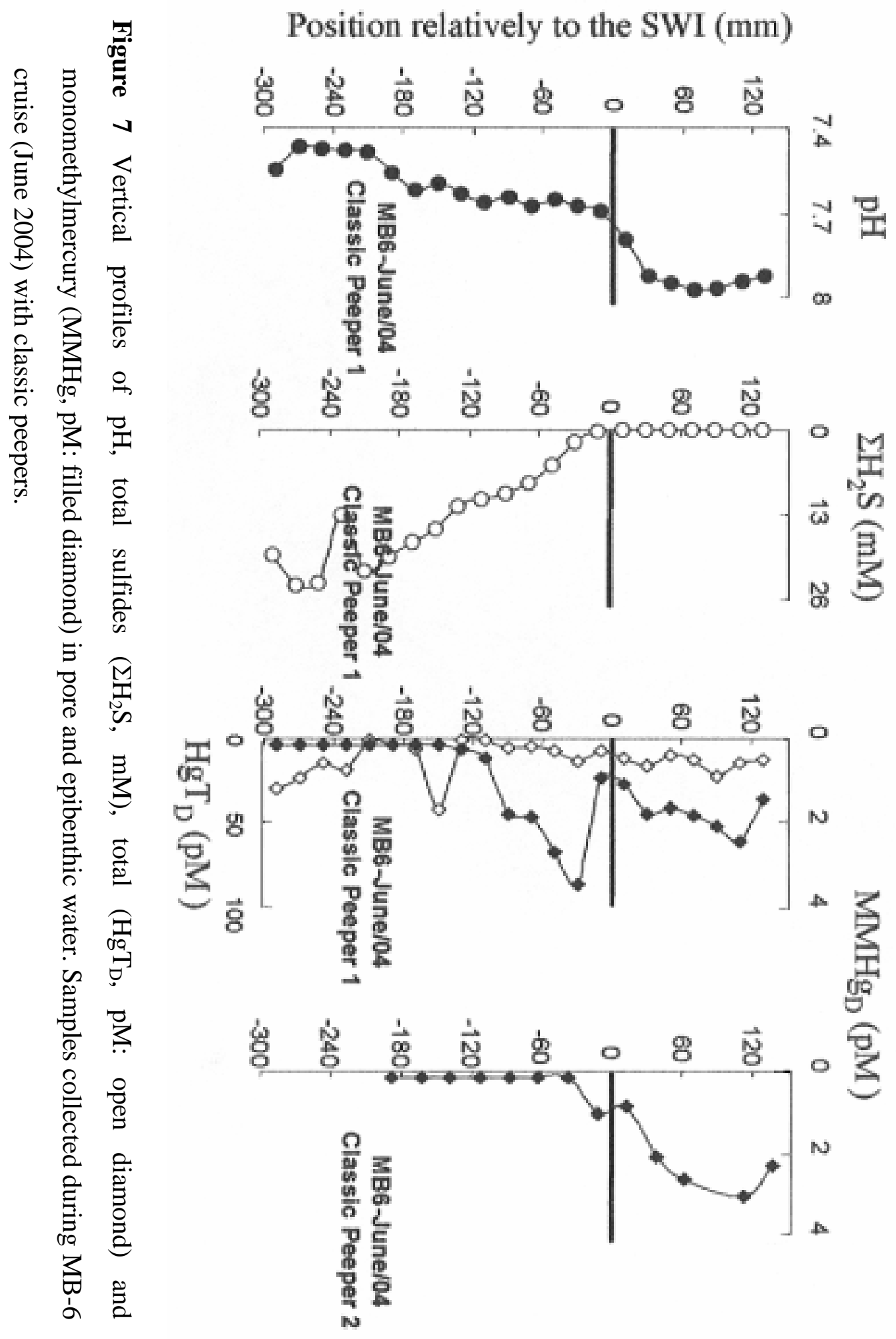




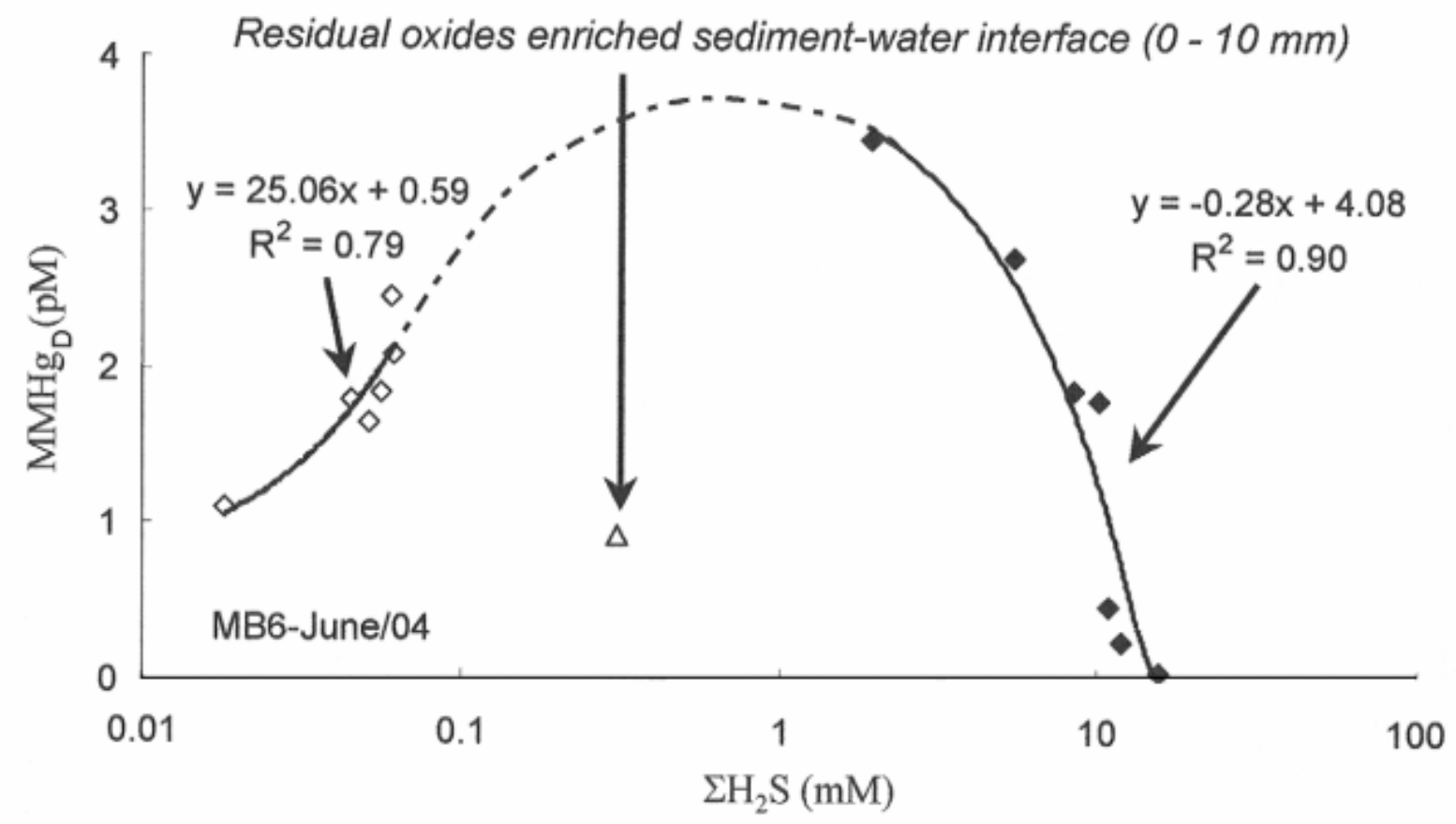

Figure 8. Relationship between monomethylmercury (MMHg$\left.{ }_{D}, \mathrm{pM}\right)$ and total sulfides $\left(\mathrm{\Sigma H}_{2} \mathrm{~S}\right.$, $\mathrm{mM}$ ) in epibenthic (open diamond) and pore (filled diamond) water. Samples collected during MB-6 cruise (June 2004) with classic peepers. 


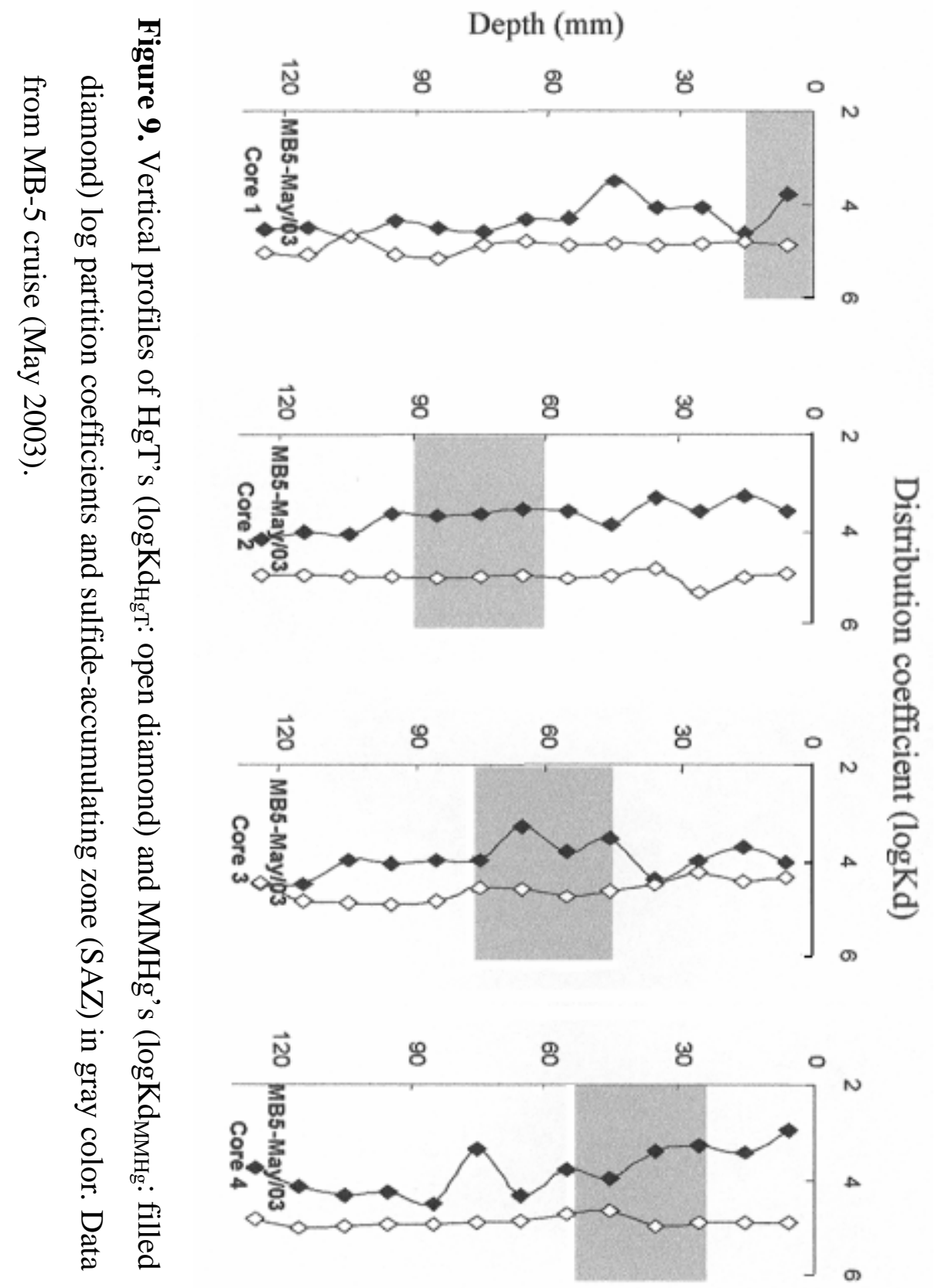




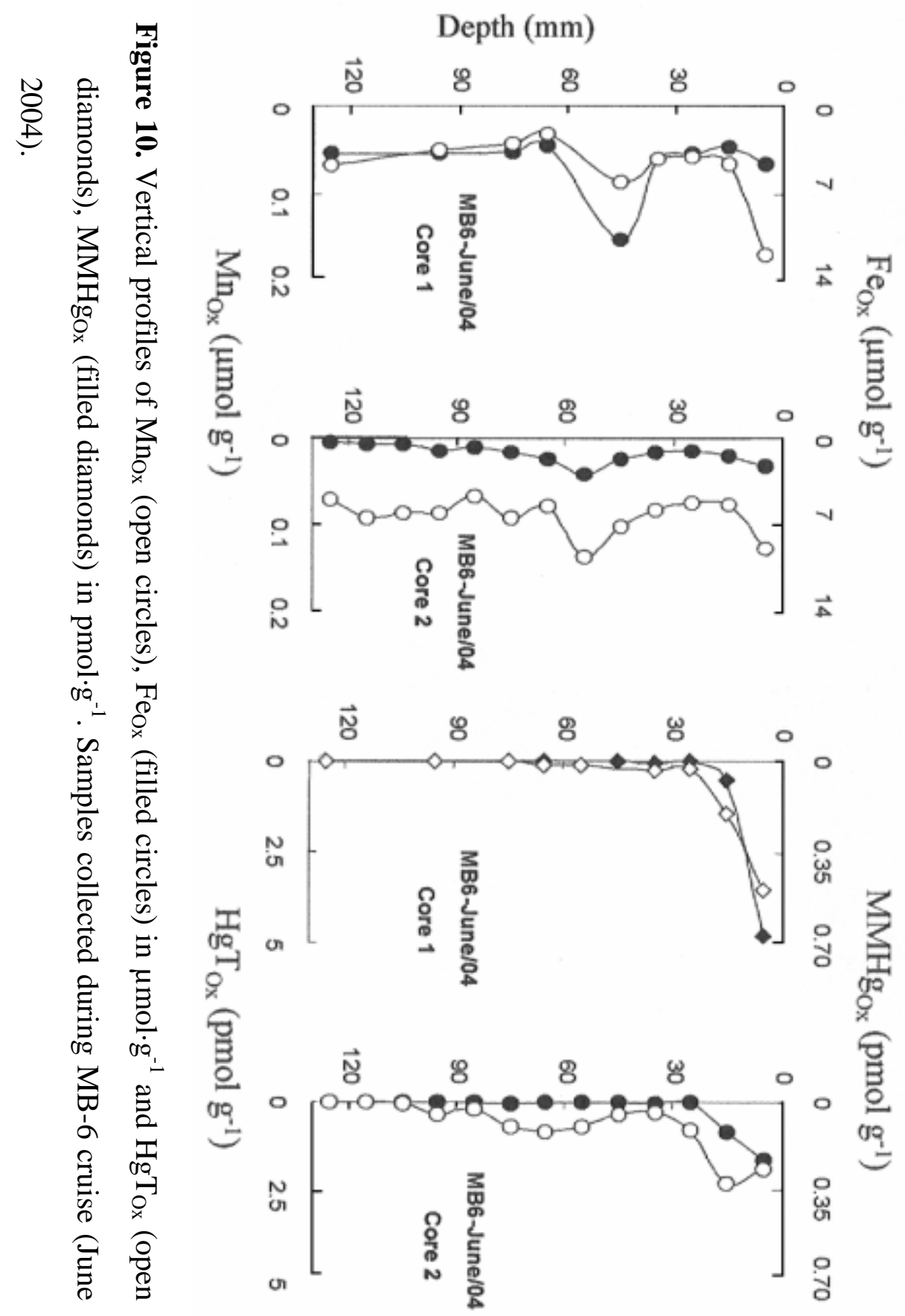

